\title{
HIKETEIA
}

To Professor E. R. Dodds, through his edition of Euripides' Bacchae and again in The Greeks and the Irrational, we owe an awareness of new possibilities in our understanding of Greek literature and of the world that produced it. No small part of that awareness was due to Professor Dodds' masterly and tactful use of comparative ethnographic material to throw light on the relation between literature and social institutions in ancient Greece. It is in the hope that something of my own debt to him may be conveyed that this paper is offered here, equally in gratitude, admiration and affection.

The working out of the anger of Achilles in the Iliad begins with a great scene of divine supplication in which Thetis prevails upon Zeus to change the course of things before Troy in order to restore honour to Achilles $;^{1}$ it ends with another, human act in which Priam supplicates Achilles to abandon his vengeful treatment of the dead body of Hector and restore it for a ransom. ${ }^{2}$ The first half of the Odyssey hinges about another supplication scene of crucial significance, Odysseus' supplication of Arete and Alkinoos on Scherie. ${ }^{3}$ Aeschylus and Euripides both wrote plays called simply Suppliants, and two cases of a breach of the rights of suppliants, the cases of the coup of Kylon ${ }^{4}$ and that of Pausanias, ${ }^{5}$ the one dating from the mid-sixth century, the other from around 470 B.c. or soon after, ${ }^{6}$ played a dominant role in the diplomatic propaganda of the Spartans and Athenians on the eve of the Peloponnesian War. From Homer, then, to the fifth century, and indeed well beyond, the social and religious institution of $i \kappa \in \tau \in i a$ figures prominently both in the traditional, mythological themes of Greek literature and in the contemporary historical record. Thus it is all the more surprising that it is almost totally ignored in what is written in standard words on the social and religious institutions of ancient Greece ${ }^{7}$ and hardly better treated

Early versions of the paper here presented were read to the J.A.C.T. Summer School in Ancient Greek at Cheltenham in July 1969 , and to branches of the Classical Association at Newcastle and Aberystwyth; the present version was read to the Oxford Philological Society in October 1972: to my audiences on all these occasions and to their criticisms I owe much. The present version was largely written in the sanctuary of the Fondation Hardt at Vandeouvres, Geneva: to the peace and hospitality of the Fondation, to its chatelaine, Mme de Marignac, and to my colleagues on that occasion, in particular Shalom Perlman and Alain and Annie Schnapp, I owe still more. Friends and colleagues have been unfailing in supplying me with information, criticism and advice: to them all, and especially to John Boardman, Nick Fisher, Peter Levi, David Lewis, Joe Loudon, Simon Pembroke and Chris Stray, I offer my thanks.

1 Il. i 407 ff., 427, 500 ff., 5 I 2 f., 557; viii 370 ff.; $\mathrm{xv} 76 \mathrm{f}$. Interestingly Chryses' appeal to the Greeks (i 12-34; cf. 370-80) is not described in language specifically descriptive of the act of supplication, but

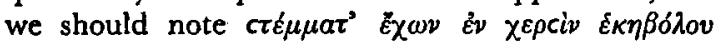

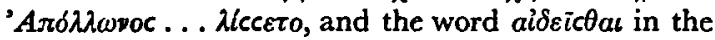
reaction of the Achaeans, on which see below, pp. $87 \mathrm{ff}$. Plato (Rep. iii 393.4) in fact refers to Chryses in lliad $\mathrm{i}$ as a ikétךe.

2 Il. xxiv $158,187,465,477$ ff., 570 .

3 Od. vi 310 f.; vii $141 \mathrm{ff}$., $155-81$.

- Herod. v 70-1; Thuc. i 126.3-12; Plut. Solon xii. shuc. i 128. I ; 133-35. I.

6 (a) Date of Kylon: Gomme, HCT i 428-30; Berve, Die Tyrannis 4I-2, 539-40. (b) Date of Pausanias: Gomme, HCT i 397-40 ; M. White, $7 H S$ lxxxiv (1964) 140-52.

7 I have been unable to discover any article on supplication in Pauly-Wissowa or in Der Kleine Pauly; the articles in Daremberg-Saglio on 'asylia' (E. Caillemer) and 'hospitium' (C. Lécrivain) contain

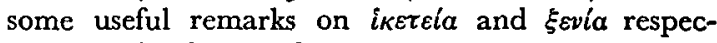
tively. The best and most perceptive treatment to date is certainly J. Kopperschmidt, Die Hikesie als dramatische Form (diss. Tübingen, 1967) I I-53; by

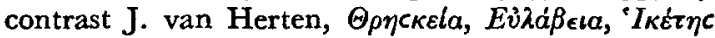
(diss. Utrecht, 1934) seems both superficial and overschematic. There are useful discussions of the language of supplication in A. Corlu, Recherches sur les mots relatifs d l'idée de priere d'Homere aux tragiques 293-324, esp. 298-301, 3 I 3-14 and J. H. H. Schmidt, Synonymik der gr. Sprache, i $177-98$. Some briefer but useful discussions: E. Schlesinger, Die gr. Asylic (diss. Giessen, 1933) 28-47; H. Bolkestein, Wohltätigkeit und Armenpflege im vorchristlichen Antike 91-3, $128 \mathrm{f}$, 244-8; P. Ducrey, Le Traitement des prisonniers de guerre dans la Grece antique $56 \mathrm{f}$, 295-300; K. Latte, Heiliges Recht 102-8; L. Gernet, Anthropologie de la Grece antique 230-3, 295-9; E. Benveniste, Le Vocabulaire des institutions indo-européennes i 92-10 I, 335-53 (on hospitality and $\varphi(\lambda l a)$; ii $245-54$ (on prayer and supplication). 
in discussion of Greek literature. ${ }^{8}$ The present article sets out to provide a modest and partial account both of the institution as a ritual act and of its place and significance in the fabric of Greek social institutions. In what follows I shall consider together the two main forms of $i \kappa \epsilon \tau \epsilon i a$, that is supplication of a human being (or a god) face to face and supplication through contact with the altar of a god or more generally his $\tau \epsilon^{\prime} \mu \epsilon \nu o c$, even though the ritual acts themselves differed in some respects in their outward form: both are covered by the Greek term and its cognates, ${ }^{9}$ and as we shall see there is both a parallelism of function and a network of resemblances between the two. On the other hand, I shall ignore for the

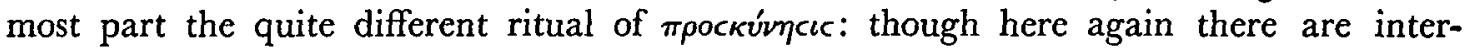
connections, it is important to distinguish the two acts more clearly than has often been the

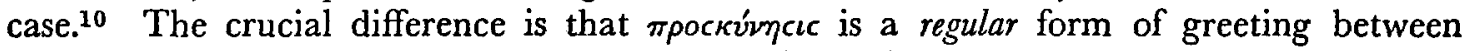
social superior and inferior, as Herodotus (i 134.1 ) and Aeschylus (Persae 150 ff.) make clear,

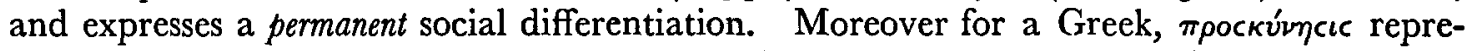
sented a form of self-abasement appropriate only as between man and god and its function did not extend beyond the unilateral conferment of honour by such self-abasement, whereas

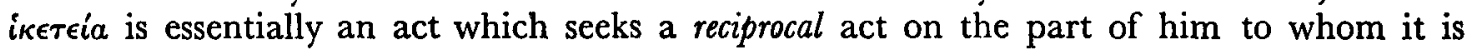
addressed, above and beyond the concepts of reciprocity which are built into the structure

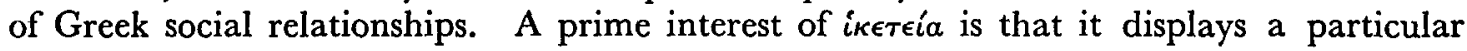
instance of the ritualisation of reciprocity around a value (prestige) of universally accepted significance in the society of ancient Greece.

\section{The act of supplication}

I shall begin by attempting an 'ethnographic' description of the act itself.

(a) Supplication of a human being (or of a god) face to face.

Detailed and precise descriptions of an action, even one of such ritual significance, are not common in Greek literature, and in the case of supplication, mostly early. But they suffice to produce an adequate picture. Perhaps the earliest and certainly one of the most indicative is the description of Thetis' supplication of Zeus in Iliad i;

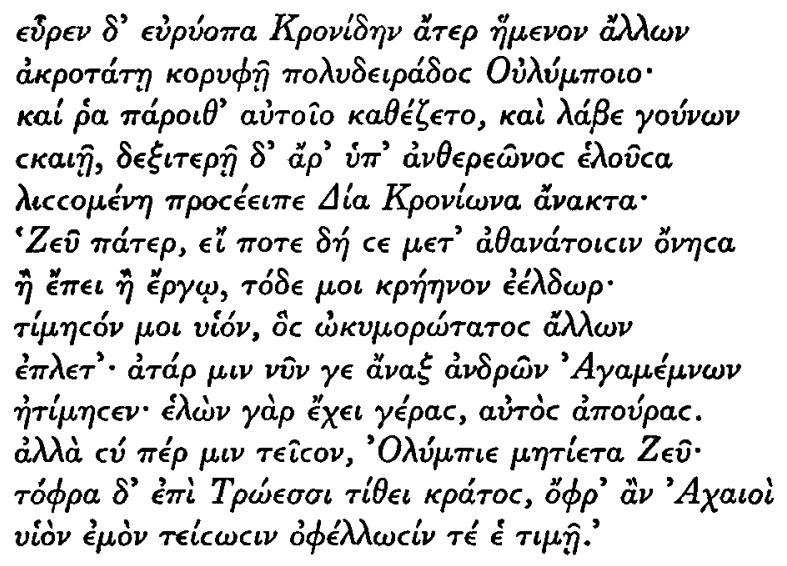

8 For tragedy, see above all, J. Kopperschmidt, Die Hikesie $54 \mathrm{ff}$.

- See the works by Corlu, Schmidt and Benveniste cited in $\mathbf{n} .7$ above.

10 For the distinction, see especially Sitt1, Die Gebärden der Griechen und Römer $157-8,169-71 ; 178$

n. $8 ; 182$ n. 7 ; H. Bolkestein, Theophrastus' Charakter der Deisidaimonia als religionsgeschichtliche Urkunde (RGVV 2 r.2 [1929]) 23-39. For a case where a failure to distinguish has misled, see Euripides: Medea, ed. D. L. Page, xix: Medea's acts are examples of

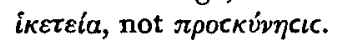


JOHN GOULD

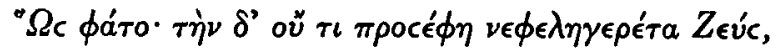

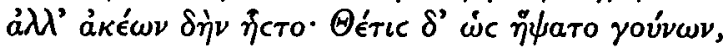

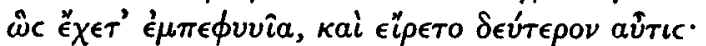

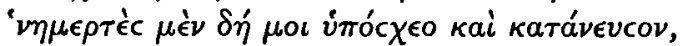

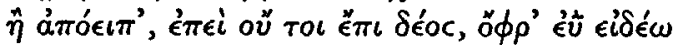

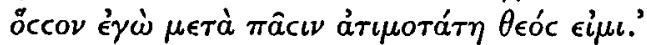

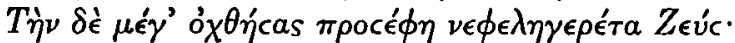

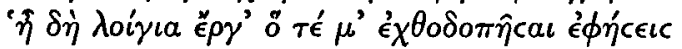

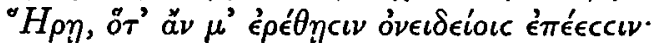

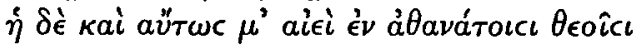

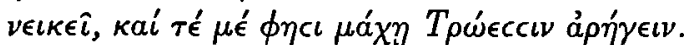

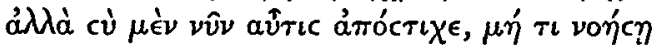

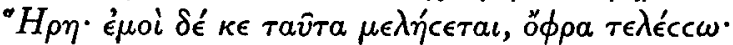

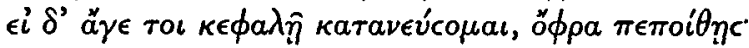

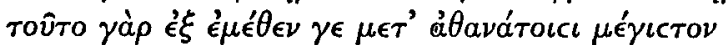

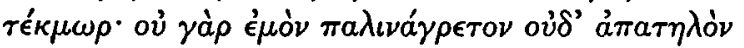

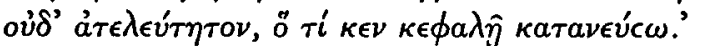

Iliad i $498-527$.

Zeus is sitting when Thetis finds him on Olympus. She herself also crouches ( $\kappa a \theta \epsilon$ '́ $\epsilon \tau o$ )

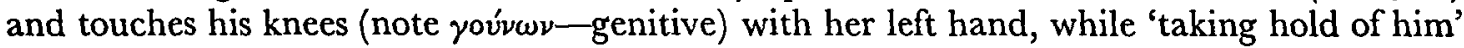
( $\left.\dot{\lambda} \lambda_{o v} c a\right)$ under the chin with her right. A later reference to the same act (Il. viii $370 \mathrm{ff}$.) adds the further gesture of kissing the knees of the person supplicated. ${ }^{11}$ Thetis' speech of

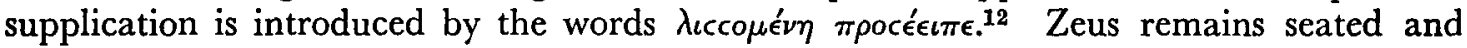
silent; Thetis continues to touch him (indeed the phrase $\ddot{\epsilon}_{\chi \epsilon \tau} \dot{\epsilon} \mu \pi \epsilon \phi v v i \alpha$ conveys something altogether stronger, a kind of graft or symbiosis) $:^{13}$ she forces a reply from Zeus by a remark that he can only take as an insult, and he agrees to grant her request. The significant elements in this sequence of actions are those of lowering the body and crouching (sitting or kneeling), of physical contact with knees and chin, and of kissing. Of these gestures, only touching the knee is found exclusively in the act of supplication, ${ }^{14}$ and we shall see supplication in some sense can be said to take place without any of them, but together they constitute the ritual act in its 'complete' or strongest form. ${ }^{15}$ They reappear constantly in Homeric descriptions of the act of supplication, with the addition of a third significant part of the

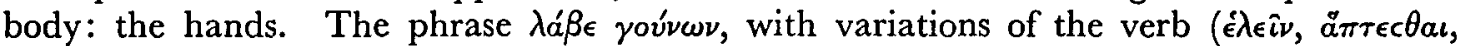
etc.), occurs 19 times in the Iliad, and a further 19 in the Odyssey, always with reference to

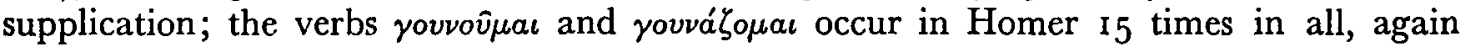
always in descriptions of supplication. Touching the chin we encounter once more only

11 Compare the (fictitious) supplication by Odysseus of the Egyptian king: Od. xiv $276 \mathrm{ff}$. ( $\kappa$ ćca yoúvat' $\varepsilon \lambda(\dot{v} v)$.

12 The verb $\lambda i c c \varepsilon c \theta a \iota$ occurs some 80 times in the Homeric poems, in contexts by no means all of which can unequivocally be classed as acts of supplication: see Corlu, Recherches $293 \mathrm{ff}$.

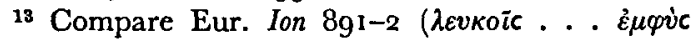
$\kappa a \rho \pi \circ \tilde{\imath} \iota \iota \nu$ $\chi \varepsilon \iota \rho \tilde{\omega} \nu$ of Apollo seizing Kreousa in the rape scene) and Hecuba 246 (Odysseus touches

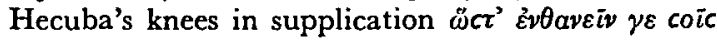
$\left.\pi \dot{\varepsilon} \pi \lambda \circ \iota c \iota \quad \chi \varepsilon i \rho^{\prime} \dot{\varepsilon} \mu \dot{\eta}^{\prime} \nu\right)$. For the associations of Émpĩva, cf. Il. vi $253=$ Od. ii $302=\times 280$ etc. and

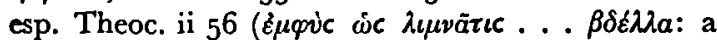
leech!).

14 Touching the chin: Od. xix 473 (Eurykleia to
Odysseus; greeting, not supplication); for other examples, see Neumann, Gesten und Gebärden in der gr. Kunst 68-70. Kissing: Od. xvi 16 ff. (Eumaios to Telemachus, again greeting: note $\kappa u ́ c \varepsilon v ~ \pi \varepsilon \rho \iota \varphi v ́ c)$; xxi $222 \mathrm{ff}$. (Odysseus to Eumaios and Melanthios, again greeting).

15 Contact can be made with one hand or with both ( $c f$. Sittl, Gebärden I63-6) : contrast, e.g., Lykaon

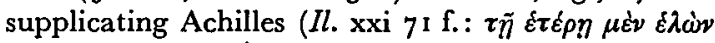

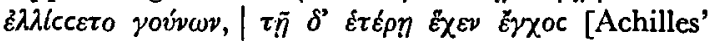

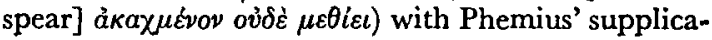
tion of Odysseus (Od. xxii $340 \mathrm{ff}$.), in which Phemius lays down the lyre which he has been holding (ibid. $33^{2}$ ) in order to have both hands free for the act of supplication. 
in the Iliad (Il. $\times$ 454). Touching (and kissing) the hands occurs most unforgettably in Priam's supplication of Achilles (Il. xxiv $477 \mathrm{ff}$.): there is no other reference in Homer to touching hands as an act of supplication.

Throughout, the ritual nature of the act depends essentially upon physical contact with parts of the body which, it has been argued, are regarded as having a peculiar sanctity. ${ }^{\mathbf{1 6}}$ Yet it is possible to go through the verbal forms of the act of supplication (for example, by using phrases such as yovvovinai $\epsilon \epsilon$ or $i \kappa \epsilon \tau \epsilon \dot{v} \omega \epsilon \epsilon)$ without such physical contact. The classic instance of what I shall call 'figurative' supplication ${ }^{\mathbf{1 7}}$ is perhaps Odysseus' supplication of Nausikaa in Odyssey vi r4 I ff., where Odysseus, having debated whether to take hold of her

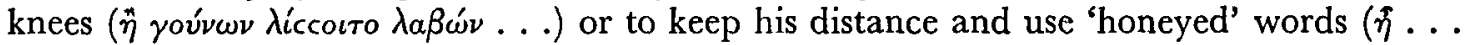

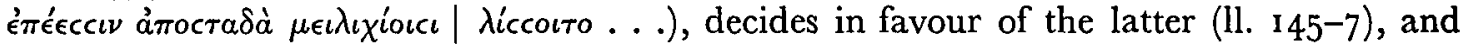
yet begins his speech: ' yovvovimai $c \epsilon$, àvacca . . . I It will become clear in what follows that such acts of purely 'figurative' supplication are without the full ritual significance of the completed act, and are adopted either where the situation requires no more than an intensification of the language of diplomatic appeal (thus Telemachus in appealing to Nestor and Menelaus for information: Od. iii $9^{2} \mathrm{ff}$. $=$ iv $332 \mathrm{ff}$.) $)^{\mathbf{1 8}}$ or where circumstances rule out or make unwise the completed ritual. The distinction between 'complete' and 'figurative' supplication is crucial if we are to understand the response of the person supplicated and of such bystanders as there may be. ${ }^{19}$ Moreover, the Homeric evidence suggests, if it does not prove, that an 'abandoned' act of supplication, that is one in which physical contact with the person supplicated is lost or broken, loses its full binding force, and this is what we ought to expect in view of the ritual significance of contact: it is also paralleled in the case of supplication through a god. ${ }^{20}$

\section{(b) Supplication by contact with an altar of a god or other sacred ground.}

This aspect of supplication has attracted considerably more attention, particularly through its development into the political and social institution of áculía by a process of secularisation which lies outside the scope of this article. 21 There is no actual example of

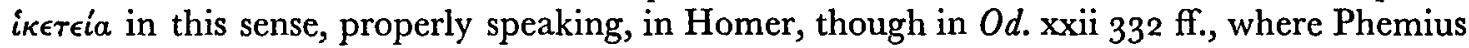
considers how to protect himself against the onslaught of Odysseus, the alternatives that

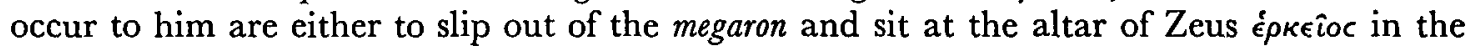
$a \dot{v} \lambda \eta^{\prime},{ }^{22}$ or to supplicate Odysseus face to face: he chooses the latter. When he and Medon are spared by Odysseus, they both sit at the altar é $\kappa$ 申óvov (xxii 375-80). Moreover, Odysseus' supplication of Arete and Alkinoos has, as it were, two stages: after touching the

18 See Onians, Origins of European Thought 97, I 32 f., 174 f., I80 f., 233, 235; Kopperschmidt, Die Hikesie 21-5; Pliny $\mathcal{N} . H$. xi 103 . For the crucial importance of physical contact, see below, pp. $78 \mathrm{f}$.

17 The distinction here adopted between 'complete' and 'figurative' supplication corresponds to Kopperschmidt's distinction between 'formel' and 'formlos'; Die Hikesie $20 \mathrm{f}$. Compare also, in Raymond Firth's account of the respect-gestures of the Tikopia: 'Whereas the [pressing of] nose to wrist and to knee is not uncommon in the more formal circumstances of Tikopia social life, nose to foot is very rare. Indeed, while theoretically it is an abject bodily apology made by someone who has insulted a chief, it is rather a verbal expression used to indicate that apology; it is figurative rather than actual. In this form it was used as a token of respect by a chief addressing his traditional gods.' ('Postures and gestures of respect' in Échanges et Communications: Mélanges Lévi-Strauss 200).
18 Or Electra begging the unrecognised Orestes to take a message to her brother (Eur. $E l .302,332$ ), a message which he has already offered to take $(292-3)$.

10 See below, pp. 80 ff.

${ }^{20}$ See Nilsson, Geschichte der gr. Religion, $\mathrm{i}^{3} 77$ f. and below.

21 See especially, E. Schlesinger, Die gr. Asylie, and artt. asylon, asylie, etc. in $R E$ ii $1881-6$ (Stengel), Daremberg-Saglio, i 505-1o (Caillemer), Hastings Encyclopedia of Religion and Ethics, ii $16 \mathrm{I}-4$ (E. Westermarck); Ducrey, Le Traitement des prisonniers de guerre 295-300; D. van Berchem, Mus. Helv. xvii (rg6o) 2 I-33; Nilsson, GGR $\mathrm{i}^{3} 77 \mathrm{f}$.

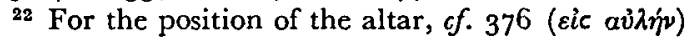
and compare Priam's pouring of a libation to Zeus

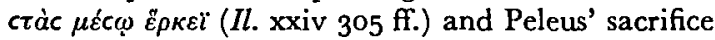

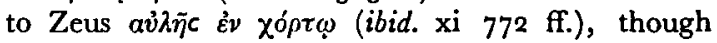
in neither place is there explicit mention of an altar. 


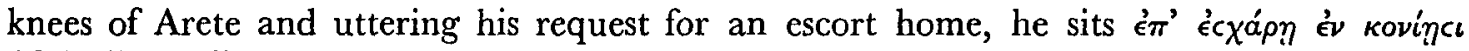
$\left(O d\right.$. vii ${ } 53 \mathrm{ff}$.: note $\left.\chi \alpha \mu a i^{\prime}\right)$ and remains there until his supplication is accepted. ${ }^{23}$ Outside of Homer, supplication through a god in this way is much more common: in the tragedians both types of supplication occur frequently, and in the historians and orators the second is by far the commoner form. ${ }^{24}$ The crucial link with the first form of supplication is the ritual significance of physical contact: as Nilsson has pointed out, ${ }^{25}$ Plutarch's account of the supplication of Kylon's associates, by tying themselves with a rope to the base of Athena's statue, whether historically accurate or not, preserves an essential element in the ritual. $\mathrm{He}$ compares the action of the Ephesians in connecting the walls of their city to the temple of Artemis, some seven stades away, so as to render their defences inviolable in the face of Kroisos' attack. ${ }^{26}$ Herodotus describes their action by saying that they 'dedicated' their city (ả $\ell^{\prime} \theta \epsilon c a \nu \tau \dot{\eta}^{\nu} \pi o^{\prime} \lambda \nu$ ) to Artemis: we shall encounter similar language in connection with supplication more strictly defined. In the case of the Kylonian conspirators, the breaking

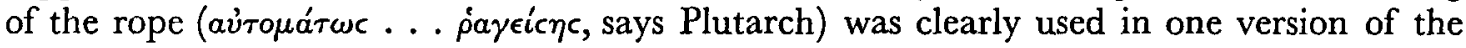

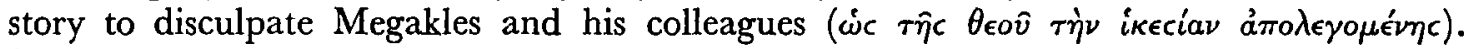
So long as contact was unbroken there was no question but that any violence brought against the suppliant was a direct challenge, either to the power of the god whose sanctuary or altar was involved to protect his own suppliants, ${ }^{27}$ or more generally to the power of Zeus ikécıoc, ${ }^{28}$ and though such cases of direct violence occur, they are much less common than a variety of methods to circumvent the protection of the god by finding some 'nonviolent' means of breaking the physical contact of supplication (the inverted commas are deliberate: a kind of practical casuistry or 'gamesmanship' is commonly found in connection with both forms of supplication). ${ }^{29}$ But first we must look at the proper, ritually correct, response of the person supplicated.

\section{The response of the supplicated}

One of the most vivid and informative of Homeric accounts of supplication is the description of Odysseus' supplication in the palace of Alkinoos on Scherie. As we have seen, Odysseus releases contact with the person of Arete, and sits on the hearth in the ashes (I shall consider later the ritual symbolism of this act). ${ }^{30}$ Silence follows, and neither Arete

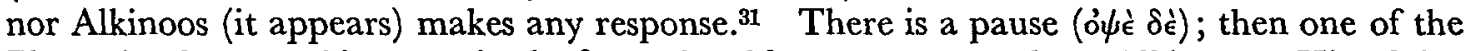
Phaeacian heroes taking part in the feast, the oldest present, speaks to Alkinoos. His advice

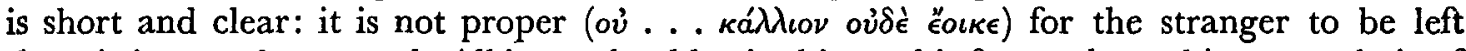
thus sitting on the ground; Alkinoos should raise him to his feet and seat him on a chair of

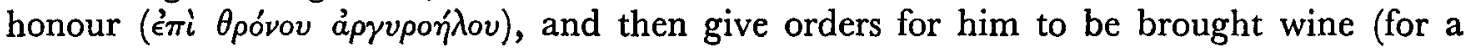

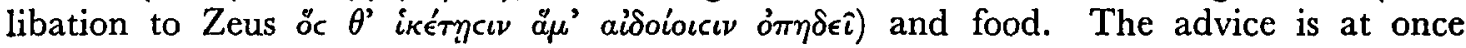
accepted. Alkinoos takes Odysseus by the hand ( $\chi \epsilon \iota \rho \dot{c} \epsilon \hat{\epsilon} \lambda \omega^{\prime} \nu$ ), raises him and sits him on a seat next to himself, from which he has required his own son Laodamas to move: the closeness of father to son is emphasised ( $\left.\mu a^{\prime} \lambda \iota c \tau a \delta \varepsilon^{\prime} \mu \iota \nu \phi \iota \lambda \epsilon_{\epsilon}^{\prime} \epsilon \kappa \epsilon\right)$. Water is brought, poured

${ }^{23}$ On the significance of the hearth in this scene, see below pp. $97 \mathrm{f}$. In $O d$. xix $388 \mathrm{f}$. Odysseus sits $\dot{\varepsilon} \boldsymbol{x} \dot{\varepsilon}<\chi a \rho \delta \varphi \nu$ in the tense moments before Eurykleia washes his feet, and some ritual significance may be intended: on the other hand, a MSS. variant offers $\dot{\alpha} x^{\prime} \dot{e} c \chi \alpha \rho \delta \phi i \nu$.

${ }^{24}$ For iketeia in the orators of a man face to face, see, for example, Lysias i 25, 29 ('figurative', since the suppliant's hands are tied behind his back): the

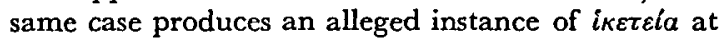

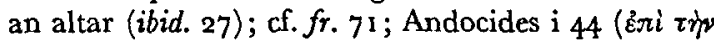

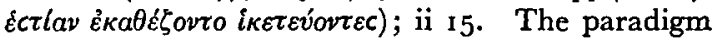
case of 'figurative' supplication, that of an orator 'supplicating' a jury, is already common in Lysias: iv 20 ; vi $55 ; \mathrm{xV} 23$; xviii 27 ; $\mathrm{xxi} 2 \mathrm{I}$; xxii $2 \mathrm{I}:$ cf. Antiphon, fr. 77 .

25 Nilsson, GGR i loc. cit.; Plut. Solon xii 1.

26 Herod. i 26; Polyaenus Strat. vi 5o. See also below, n. 121.

27 Compare the story of Aristodikos and Apollo, below p. 84 .

28 See Roscher, Ausführliches Lexikon der gr, und röm. $M y t h o l o g i e$ vi 63 I ff.; $R E$ viii 1592 f. (art. Hikesios: Jessen); H. Lloyd-Jones, The Justice of Zeus 30.

${ }^{20}$ See below pp. $82 \mathrm{f}$.

so See below pp. 97 f. $\quad 31$ Od. vii $154 \mathrm{ff}$. 
from a golden jug over a silver bowl, so that Odysseus may wash his hands; a table is set by Odysseus, food (and presumably drink: $\pi \hat{\imath} \nu \epsilon \kappa a i \hat{\eta}(\theta \epsilon)$ served; then follows a libation. Arete, we should note, remains silent and does not speak until the guests at the feast have gone home and she is alone with her husband and the suppliant Odysseus (Od. vii $230 \mathrm{ff}$.). Each stage of this procedure has clear ritual and symbolic significance. The act of first raising Odysseus to his feet by taking him by the hand is symbolic both of acceptance within the social group and of the conferment of honour: ${ }^{32}$ Odysseus' act of sitting signifies acceptance on his part of the relationship. ${ }^{33}$ The pouring of water over his hands and the act of libation are both, of course, ritual acts, the latter of which also serves to create a bond of solidarity. ${ }^{34}$ The offering and acceptance of food creates a further ritual bond of solidarity between the participants. ${ }^{35}$ Thus the significance of the sequence of actions

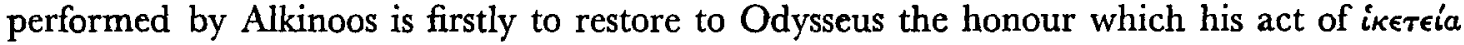
has disclaimed, and secondly to enact his acceptance into the social group of which Alkinoos is head and representative agent, to change him (we might say) from $\xi$ 'voc in the sense of

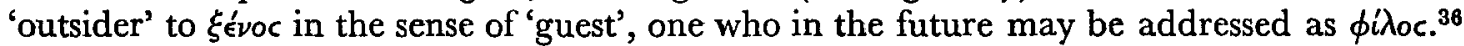
In all this the response of the supplicated is in almost all respects the same as that of the $\xi \epsilon \iota \nu 0 \delta$ ókoc who receives a guest without the addition of the ritual of supplication. Nor is this merely because in this instance Odysseus' role is perhaps capable of being interpreted as being that of 'guest' just as much as that of 'suppliant': it is, as we shall see, because of a systematic parallelism between the two roles and their function within the structure of social relationships. ${ }^{37}$ When Achilles accepts the supplication of Priam, the sequence of his acts is closely parallel to those of Alkinoos, though the smoothness of the sequence is very much threatened by the overwhelmingly greater tension inherent in the situation. Achilles takes Priam by the hand and pushes him gently away (Il. xxiv 508; the sequence is then interrupted by the storm of grief that floods over both men together). Then Achilles raises Priam to his feet (ibid. $5^{15}$ ) and invites him to sit $\left(5^{22} \mathrm{f}\right.$.); Priam refuses ( $553 \mathrm{ff}$.), and at

32 For the act of raising a suppliant to his feet, note also the Molossian king, Admetos, with Themistokles (Thuc. i 137.1 a $v i c \tau \eta c \iota . .$. avंzov); for the conferment of honour, see below n. 107 .

ss Hence Priam's refusal to sit when a suppliant to Achilles until the body of his son is returned to him (Il. xxiv 521-2; 553-5; Achilles had already taken him by the hand, ibid. 508): we should, I think, compare Patroklos' refusal to sit when invited by Nestor (Il. xi 645 ff.), though there mere urgency would provide a 'rationalising' explanation.

34 For the ritual significance of washing in Homer, see, for example, L. Moulinier, Le pur et l'impur dans la pensée des Grecs 26-8 and, more generally, 71-3; J. Rudhardt, Notions fondamentales de la pensée religieuse et actes constitutifs du culte dans la Grece classique 240: I do not see how we can, with Moulinier, distinguish between the purely secular ('hygienic') washing of some passages and the ritual purification of others: all such acts are ritual, all equally are 'hygienic'. The distinction is meaningful only to the outside observer. In any case, the present passage precedes one act (libation) of unambiguously ritual significance: see also Hesiod, Works and Days, $724 \mathrm{ff}$. For the significance of libation, Rudhardt, op. cit. 240-5; for the bond of solidarity, Rudhardt, $244-5$ and next note. On the whole question of 'purification' and hygiene, see Mary Douglas, Purity and Danger: an analysis of concepts of pollution and taboo.
35 On the significance of the common meal in creating solidarity, see J. Rudhardt, Notions fondamentales $15^{8-60}$ and more briefly but penetratingly, M. I. Finley, The world of Odysseus 145-6; J. Kopperschmidt, Die Hikesie $33-4$. For the binding force of the common meal, see esp. the reference to the 'table of $\xi \varepsilon v / a^{\prime}$ along with the hearth and Zeus himself in Odysseus' oath at $O d$. $x i v \quad 15^{8 \mathrm{f}}=\mathrm{xvii} \quad 155 \mathrm{f}$. $=$ xix $303 \mathrm{f}$ : $=\mathrm{xx} 230 \mathrm{f}$. and $I l$. xxi 75-7 (Lykaon to

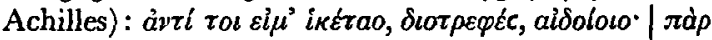

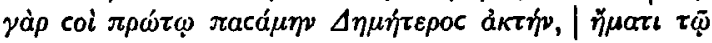
$\delta \tau \varepsilon \mu^{\prime} \varepsilon[\lambda \varepsilon c \ldots$. . (The force of $\pi \rho \omega \dot{\tau} \omega$ ) is also important: 'you were the first with whom . . $\therefore$ : the plea is rejected, but on this, see below p. 8o; further Od. xxi 27-9, 34-8). Note Odysseus' refusal to eat or drink with Kirke until his companions have been transformed back into human form: Od. $\times 3^{8} 3 \mathrm{ff}$. For later Greek belief, Deinarchos, in Dem. 24 ( $\delta \mu$ ócrowdoc

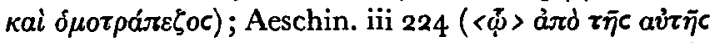

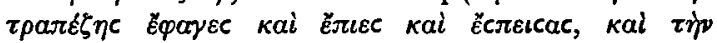

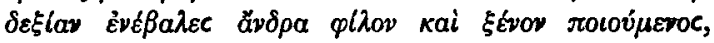

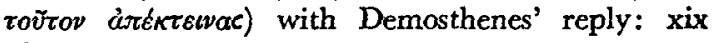
$189-91$.

so Note that though Achilles does not accept Lykaon's supplication, he nevertheless addresses him as piloc ( $I l$. xxi ro6) after being reminded of the common meal.

${ }^{37}$ See below pp. $90 \mathrm{ff}$. 
this point the tension comes close to erupting in murderous violence $\left(559 \mathrm{f} ., 5^{68-70}\right)$, until Priam sits. After arranging for Hector's body to be prepared for its restoral, Achilles returns, sits against the opposite wall (596-8), and offers Priam food and drink, which he accepts. Before they sleep, Achilles takes Priam once more by the hand (671-2).

Thus the proper ritual response to the act of supplication. But, of course, supplication may be rejected in both the Iliad and Odyssey. ${ }^{38}$ There are some 35 occurrences of supplication in the Homeric poems, some of which are merely reported in the course of a speech or imagined in very general terms (for example, Achilles in $I l$. xi $6 \circ 9 \mathrm{f}$. imagines the Greeks 'about his knees'). ${ }^{39}$ Of those whose outcome is at all clear, some twenty-two are accepted, another ten unsuccessful. But it is important to observe the circumstances that accompany unsuccessful supplication in Homer, and the reactions of those supplicated in such cases, with some precision. The most direct affront to the rite of supplication is that offered by Agamemnon and Menelaus to Adrastus in $I l$. vi $45 \mathrm{ff} .^{40}$ Adrastus has been thrown from his chariot and finds himself lying in the dust with Menelaus standing over him, spear in hand. He touches Menelaus' knees and offers ransom. Menelaus is all but persuaded $\left(\theta \nu \mu \dot{o} \nu . . . \epsilon^{\prime \prime} \pi \epsilon \bullet \epsilon\right)$, but Agamemnon arrives at a run and reminds him in scornful rhetorical questions of his humiliation at the hands of the Trojans: total and ruthless revenge alone can restore his honour. Menelaus' mind is changed, and he thrusts Adrastus away from him with his hand $(62 \mathrm{f}$.), whereupon Agamemnon kills him with a spear-thrust under the ribs; Adrastus falls back and Agamemnon with his foot on his chest pulls out the spear. Two things should be noted here: firstly, that it is Agamemnon, not Menelaus to whom the supplication has been addressed, who carries out the killing, and secondly, that it is not until physical contact between suppliant and supplicated has been broken that violence is offered to Adrastus. Nevertheless physical force is used here to break the binding hold of the suppliant's touch, and that is rare. The case of Lykaon is a little different (Il. xxi $64 \mathrm{ff}$.).

Lykaon has already once been captured by Achilles on a night-raid, and sold into slavery (ibid. 35-44). This time Achilles is determined that he shall not reappear on the battlefield again, unless the earth gives up her own (60-4). Achilles raises his spear ready to thrust home, Lykaon ducks and runs beneath the spear, touching Achilles' knees: the spear sticks fast in the ground behind him. With one hand on Achilles' knees, the other

38 Though Dodds, Greeks and the Irrational 32 and 52 n. 19 , is right in pointing out that the Iliad has no reference to Zeus as protector of suppliants, his apparent implication that in the Iliad (by contrast with the Odyssey) suppliants are never spared and supplication never successful is misleading (so too Wilamowitz on Hesiod, Works and Days 327) : though it is true that no successful supplication on the field of battle is described in the Iliad, such are implied in the references to capture alive and sale into slavery (e.g. xxi 77 ff., I0I-2; xxii 45 ; xxiv $75^{\prime}$ ff.). For a case of rejected supplication in the Odyssey (apart from the case of the Cyclops), see $O d$. xxii $210 \mathrm{ff}$. (Leodes to Odysseus).

39 The cases are as follows: Iliad i $407 \mathrm{ff}$., 427 , $500 \mathrm{ff}$., $512 \mathrm{f}$., 557 + viii $370 \mathrm{ff}$; $\mathrm{xv} 76 \mathrm{f}$. (Thetis to Zeus); vi $45 \mathrm{ff}$. (Adrastus to Menelaus); ix $45 \mathrm{I} \mathrm{ff}$. (Phoenix' mother to Phoenix); ix 581 ff. (Oineus to Meleager [?]); x $454 \mathrm{ff}$. (Dolon to Diomedes); xi $130 \mathrm{ff}$. (Peisander and Hippolochos to Agamemnon); xv $660 \mathrm{ff}$. (Nestor to the Greeks); xvi $573 \mathrm{f}$. (Epeigeus to Peleus and Thetis); xviii 457 (Thetis to Hephaistos); xx $463 \mathrm{ff}$. (Tros to Agamemnon); xxi $64 \mathrm{ff}$., I 5 f. (Lykaon to Achilles); xxii 240 (Priam and Hecuba to Hector); xxii $338 \mathrm{ff}$. (Hector to Achilles); xxii 4 I 4 ff. (Priam to the Trojans [?]); xxiv I 58, i 87, $465,477 \mathrm{ff}$., 570 (Priam to Achilles). Odyssey iii $9^{2}$ (Telemachus to Nestor) $=$ iv 322 (Telemachus to Menelaus); iv 433 (Menelaus to 'the gods'); v $449 \mathrm{f}$. (Odysseus to the river-god); vi 14I ff., 147, 149, I 68 f., I 93 + vii 292, 301 (Odysseus to Nausikaa), vi 310 f.; vii $141 \mathrm{ff}$, $16_{5}=181$ (Odysseus to Arete and Alkinoos); ix $266 \mathrm{ff}$. (Odysseus to the Cyclops); x 264 (Eurylochos to Odysseus); x 324 (Kirke to Odysseus); $\times 480 \mathrm{f}$. (Odysseus to Kirke); $\times 5^{21} \mathrm{I}=$ xi 29 (Odysseus to the dead); xi 66 (Elpenor to Odysseus); xi $53^{\circ}$ (the dead Neoptolemos to Odysseus); xiii $231+324$ (Odysseus to the disguised Athena); xiv $276 \mathrm{ff}$. (Odysseus to the Egyptian king); xiv 5 Iof. + xvii 573 (Odysseus to Eumaios [?]); xv 277 (Theoklymenos to Telemachus); xvi 67 (Odysseus to Telemachus); xviii $394 \mathrm{ff}$. (Odysseus to Amphinomos [?]); xxii 3 ro ff. (Leodes to Odysseus); xxii $332 \mathrm{ff}$. (Phemios to Odysseus); $x x i i \quad 365 \mathrm{ff}$. (Medon to Telemachus). A further doubtful (imagined) case is lliad xxii $220 \mathrm{f}$. (Apollo to Zeus), on which see below n. 102 .

10 On the case of Adrastus, see Ducrey, Traitement des prisonniers de guerre $56 \mathrm{f}$. 
on the spear, Lykaon appeals and offers ransom, reminding Achilles, as we have seen, of the common meal they shared, and offering persuasive argument: he is only Hector's halfbrother. All this, evidently, with no great prospect of success (92-3). Achilles rejects the appeal in a passionate and powerful speech: Patroklos now is dead and the time for ransoms has gone; all before Troy, Achilles himself included, are doomed to die whenever the time comes. Lykaon is appalled, lets go of the spear and crouches with both hands spread out in an appeal for mercy (114-16). ${ }^{41}$ Achilles draws his sword and slashes at his neck just above the collar-bone: Lykaon dies. Now in this case, apart from the unique circumstances of the encounter, one thing stands out: it is that Lykaon has removed his hands from Achilles' knees before Achilles strikes. If we look at the sequence of actions with the strict eye of a ritualist, Lykaon is no longer a suppliant in the full ritual sense when he is killed. The fact may be insignificant, but I think not.

The third case in Homer of direct rejection of a completed supplication is Odysseus' killing of the $\theta$ vockóoc Leodes in Od. xxii 3 ro ff. Leodes throws himself at Odysseus and touches his knees: he offers a plea in his own defence, which is that he has neither done nor said anything a $\alpha_{\alpha}^{\prime} c \theta a \lambda o v$ to the women of Odysseus' palace, and has even tried to prevent the suitors from doing so, but without prevailing. We have Homer's testimony to the truth of the plea (Od. xxi $145^{-7}$, though Leodes addresses the suitors as $\phi i \lambda_{o u}, 15^{2}$ ), but Odysseus rejects it, seizes a sword lying on the floor and kills Leodes as he is in the very act of speaking $\left(\phi \theta \epsilon \gamma \gamma \circ \mu \epsilon^{\prime} v v, 329\right)$. The rejection, like those of Adrastus and Lykaon, is justified by the need for vengeance: but in this case there is nothing in the ritual procedures to mitigate the act or by casuistry to exculpate Odysseus.

The remaining Homeric examples of supplication rejected or ignored are all ones where either the act is never completed (the suppliant is killed before he can establish the physical contact in which we have seen the ritual force of the act to consist) or the supplication is purely 'figurative' in the sense described and no contact is attempted (or ruled out by circumstances). Thus in the first category, Dolon is killed by Diomedes as he is about to touch the latter's chin (Il. x $454 \mathrm{ff}$.: his hands have been seized, 377), Tros by Agamemnon as he is in the act of touching his knees and about to utter his plea (Il. xx $463 \mathrm{ff}$.: n.b. the

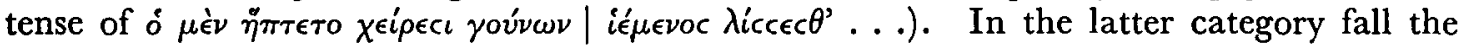

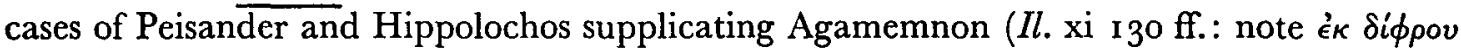

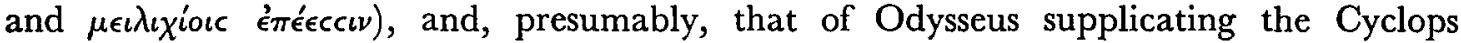
(Od. ix $266 \mathrm{ff}$.: Odysseus and his men have fled on Polyphemus' approach éc $\mu v \chi \dot{o} \nu$ ăvrpov, 236, and remain there?), though the Cyclops' reply to Odysseus' plea constitutes a rejection of the binding force of supplication as such (277). ${ }^{42}$ On the other hand, some cases of purely figurative supplication are accepted, notably Odysseus' supplication of Nausikaa

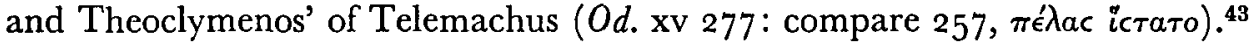

The analysis of acts of supplication and their reception by the person supplicated that I have been putting forward may strike the modern reader as disingenuous or cynical, as coming close to treating the entire ritual as a sort of game with rules that can be played to, or by. But that is precisely, I believe, the correct light in which to view the operation of a ritual act within a living framework of ritual. I do not mean to suggest that supplication was not an act to be taken seriously: quite the contrary-it is a game of life and death.

41 For the gesture, of., e.g., $I l$. iv $523=x$ iv 549 , and more closely xiv 495 f.; Sittl, Gebärden 50 n. 5, $147 \mathrm{f}$. W. H. Friedrich, Verwundung und $T_{\text {od }}$ in der Ilias 100-02, gives a perceptive analysis of the death of Lykaon, from a different point of view.

42 Hector's supplication of Achilles (Il. xxii $33^{8} \mathrm{ff}$.) is presumably to be classed as another case of rejected 'figurative' supplication: the point of Achilles' spear has passed through his neck and he falls to the

ground. He pleads for honourable burial ixìp

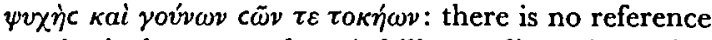
to physical contact, but Achilles replies $\mu \eta^{\prime} \mu \varepsilon \kappa v ́ o v$,

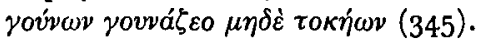

43 At one level of realisation, an extreme case of 'figurative' supplication is Odysseus' supplication of the river-god in Scherie (Od. v $445 \mathrm{f}$.: cóv $\tau \varepsilon$ póov cá

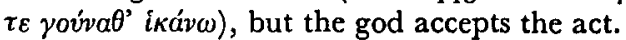


But that the notion of a game in particular may help us to make clear the inner logic of the act is made, I think, abundantly clear by the evidence. I turn now to considering this aspect of supplication in more detail, and I suggest that the analogy of a game of 'tag', in which the concept of the 'out of bounds' (hands touching the wall, feet off the ground and the like) is vital for understanding how the game is played, may prove helpful: in particular, that the notion of 'gamesmanship', that is exploiting the rules without actually breaking them, helps to make clear much that is otherwise obscure.

\section{The 'rules of the game'}

In Herodotus iii $48.1-4$ we encounter the story of the 300 Corcyrean children sent by Periander to Sardis to serve as eunuchs at the court of Alyattes. The ship carrying them to Lydia puts in at Samos, and the Samians, on learning what is going on, advise the children to seek sanctuary in the iepóv of Artemis. The Corinthians are prevented from dragging them away, or would have been if they had tried, 44 and instead attempt to starve them out, presumably by surrounding the iєpóv. Whereupon the Samians introduce a new festival into the sacred calendar, a night festival which continues all the time that the suppliants are there, and which involves choruses of girls and youths who carry sweets made of sesame and honey: the Corcyrean children seize these sweets as the dancers go past and continue to eat. Eventually the Corinthian escort of the children give up and go home. In this story, clearly, 'gamesmanship' plays a major role. The suppliants, so long as they

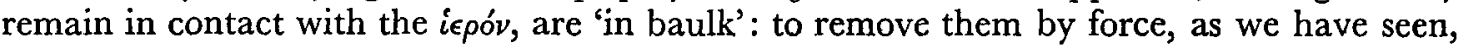
is construed by the actors as a challenge to the power of the god whose protection they have sought (and in this case would be prevented by human allies): thus the first step is to find some means short of direct physical violence which will 'persuade' the suppliants to leave their position in baulk, that is their contact with the iepóv (or, alternatively, to make them so weak that there can be no question of resistance, so that the eventual act of removal could be construed as 'voluntary'). ${ }^{45}$ This first ploy is then thwarted by a counter-ploy: the newly instituted festival allows the children to get food but cannot itself be impeded by the Corinthians without their breaking another set of rules. Stalemate results, and the Corinthians resign the game. But the rules which have now been invoked have still to be maintained, and what above all establishes the seriousness of the moves involved in the minds of the players (quite apart from what is at stake in the game for the suppliants themselves) is the fact that the Samians continue their festival (Herodotus does not say whether annually or at some longer interval of recurrence) into Herodotus' own day, for what by his reckoning is some $5^{\circ}$ years. Once again, as with the story of Ephesus, it matters not at all whether Herodotus' tale is historically accurate or not: it is the way in which patterns of thought and behaviour are thrown into relief that makes it highly significant.

Other ploys were attempted: for example, treachery (the promise of a ransom or some more complex plot), as in the case of the Argive suppliants in the sacred grove of Argos (Herod. vi 78.2-79.1) and of Agis in the temple of Athena Chalkioikos (Plut. Agis xvi I; xviii $5-7, x i x)$, or the use of fire, as with the remaining Argives when they became aware of the nature of the trick being played (Herod. vi 79.2-80), or, to move for a moment into the

\footnotetext{
4 Herodotus' language does not make it altogether clear whether an attempt was in fact made, since he

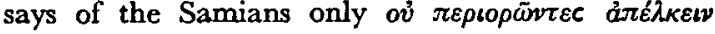

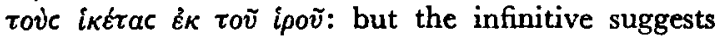
that the threat was potential, not actual.

45 For the dilemma involved (forcible removal of a suppliant or the chance that the suppliant will die on sacred ground), see Nilsson, GGR $\mathrm{i}^{3} 78$. For the use of starvation, the obvious parallel is the case of
}

Pausanias (Thuc. i 134), and his removal from the iepóv while still alive by the ephors: in that case it was adjudged by Delphi that the rules had been broken (134.4). Compare the analogous measures taken by Kreon to avoid the blood-guilt of Antigone's death (Soph. Ant. 773-6, 885-9) and the complex of 'moves' used to avoid the blood-guilt of the death of a sacrificial victim, W. Burkert, GRBS vii (1966) 106-1 1, 118 and n. 71; Homo Necans 10-20. 
world of Attic tragedy, with Amphitryon, Megara and the children of Herakles (Eur. Herakles 240 ff.)..$^{46}$

Of course, straight breaking of the rules occurs in history as in Homer: Stesippos is driven from sanctuary in the temple of Artemis near Tegea by being bombarded with tiles from the roof, and then killed (Xen. Hell. vi 5.9), an anonymous member of the Aeginetan $\delta \tilde{\eta} \mu \circ c$, clinging to the handles of the temple-doors of Demeter Thesmophoros, has his hands cut off and is then killed (Herod. vi 9I).47 More ambiguously the Corcyrean oligarchs, suppliants in the "Hpaıov, are despatched in a variety of ways in the confused (and confusing) events of 427 B.c. (Thuc. iii $70 \mathrm{ff}$.). They had been first transferred (willingly, it seems) to

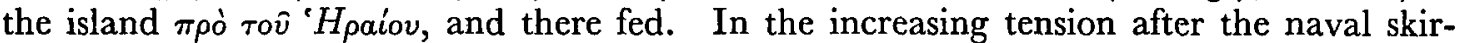
mishing they are transferred back to the "Hpalov (for the good of their opponents, it would appear, rather than their own); later again, when the Peloponnesian ships have left for home and Athenian reinforcements arrive, 50 (of an original four hundred) are persuaded to stand trial-and condemned to death (81.2). The majority, unpersuaded, offer a quick

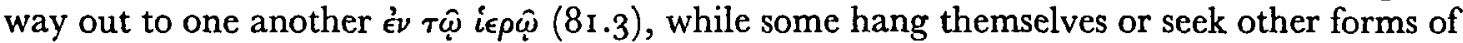

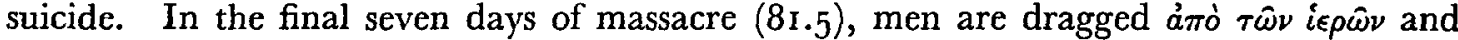

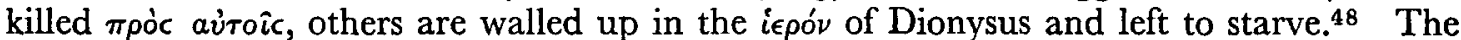
sense of shock which spreads in waves through Thucydides' comments on the Corcyra episode in iii 82-3 conveys the traumatic effect, even in the late fifth century, of happenings such as these. One last example of a straightforward breaking of the rules of supplication, one of the most direct and public of all. One of the climactic moments of the reign of terror of the Thirty is the killing of Theramenes (Xen. Hell. ii 3.52-6); even the prosaic and tightlipped Xenophon attains in his narrative a certain eloquence which conveys something of

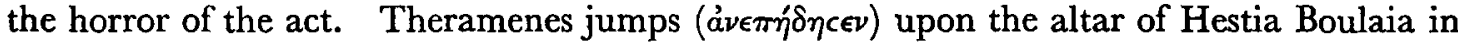
the Bouleuterion and is dragged from it by Satyros and his assistants, shouting and calling

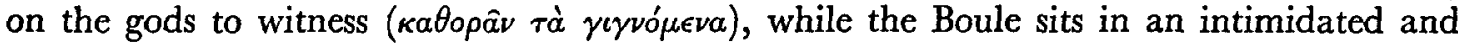

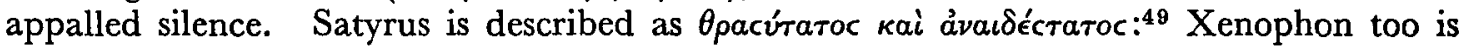
shocked.

But it is important to grasp that the inhibiting effect of an act of supplication more often provoked crises of indecision ${ }^{50}$ and virtuoso techniques of playing to the rules than it did a direct and simple resort to violence: the 'Gordian knot' solution is not the most characteristic. An idea of the agonies of decision that often attended the appearance of a ikérqe is given by Herodotus' story of Paktyes (Her. i $157-60$ ). The Lydian Paktyes, with the gold of Sardis with him, and the messengers of Kyros' emissary Mazares on his heels to take him

6 When the play opens, the suppliants are at the altar of Zeus ( $44 \mathrm{ff}$.); the tyrant Lykos is resorting to starvation $\left(5^{i-4}\right)$. When he arrives, he attempts rhetorical persuasion (140-235), and when this fails, announces that he will build a fire round the altar and burn them alive: the suppliants then leave the altar $(319 \mathrm{ff}$.$) . For a variant on the theme of$ trickery, see Andromache $309 \mathrm{ff}$ : Menelaus kidnaps Andromache's son Molossos to force her to leave her place of supplication; as she steps away, after long pleading and argument (319-412), Andromache is seized and bound. In her subsequent supplication of Peleus $\left(57^{2-4}\right)$ she cannot grasp him as her hands are still bound: she can only fall on her knees and her supplication is 'figurative'- the reference to her bound hands constitutes her fulfilment of the ritual.

47 In this case äyoc results, which the Aeginetans attempt to appease by sacrifice, but, says Herodotus, they were ejected from the island by the Athenians

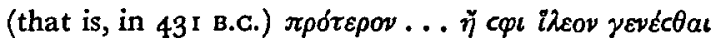
$\tau \dot{\nu} \nu \theta \varepsilon o ́ v$ : the murder of the suppliants took place, in Herodotus' view, before 490 . Here too the ritual consequences of a supplication and its violent breach last for more than half a century.

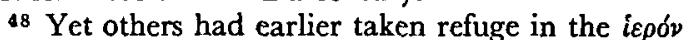
of the Dioskouroi $(75.3)$ : they are not persuaded to leave by Nikostratos, the Athenian general, and their enemies are prevented from killing them by Nikostratos. Thereafter there is no explicit reference to their fate.

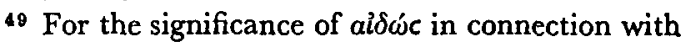
supplication, see below, section 4 (pp. $87 \mathrm{ff}$.); on Theramenes' supplication, see P. J. Rhodes, The Athenian Boule 33-4.

${ }_{50}$ Crises of indecision: $c f$. the Argive king (Aesch.

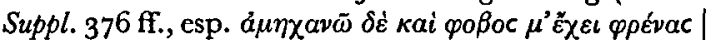

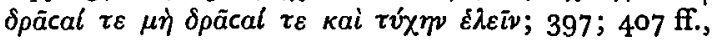
439 ff.; 468-79). 
back alive to Ekbatana, arrives as a iкé

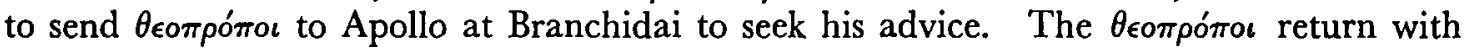
instructions to give up Paktyes, and the people of Kyme are more than ready to accept the

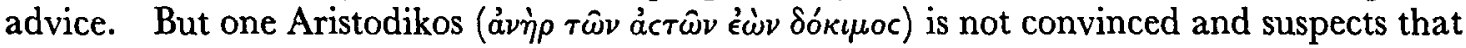

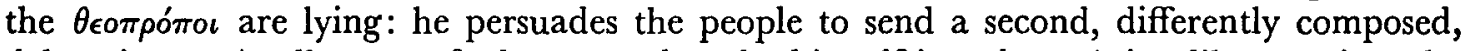
delegation to Apollo, one of whose members he himself is to be. Aristodikos receives the same instruction once again, and is not satisfied. He has prepared his next move already

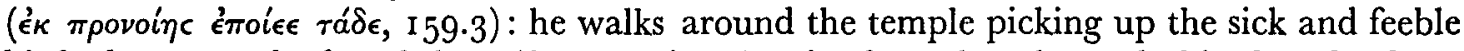
birds that are to be found there ('́) $\tau \hat{\omega} \nu \eta \hat{\omega})$. A voice from the adyton asks him how he dares

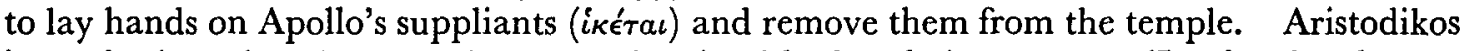

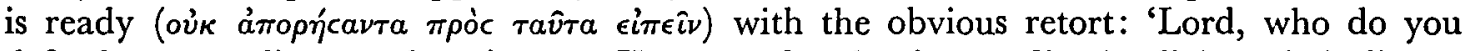
defend your suppliants and yet instruct Kyme to abandon its own?' Apollo's reply is direct:

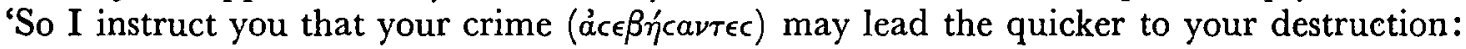
never again come to my oracle to ask advice on giving up a suppliant. ${ }^{32}$ The Kymaians are now in the full grip of the dilemma (having sought a way out and failed), and they make a move which we shall encounter again, namely that of smuggling the suppliant 'off the field': they pass Paktyes to Mytilene. Mytilene however is discovered to be negotiating with Mazares for the surrender of Paktyes for a reward: the Kymaians intervene once more (since it is not clear whether they have successfully shed responsibility), and this time

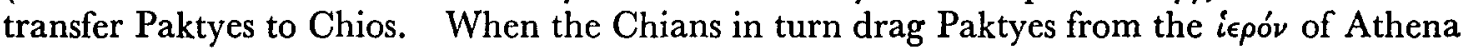
$\pi \circ \lambda$ iovyoc to hand him over to Mazares, the Kymaians are too late and the suppliant is surrendered. The Chians' reward is the territory called Atarneus on the mainland opposite: but, Herodotus tells us, for a long time they were careful not to dedicate any of the fruits of that territory to any god, and everything that came from there was excluded from the $i \in \rho a^{5} .^{53}$

The moves that I have been describing form an obvious, though neglected, part of the

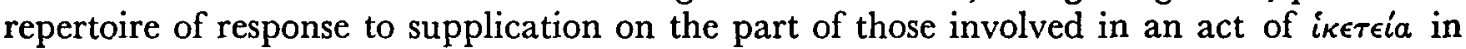
its 'sanctuary' form. But similar manoeuvres are attempted also in the other form of face to face supplication. In Euripides' Hecuba Polyxena is to be sacrificed to the dead Achilles; Hecuba attempts 'figurative' supplication of Odysseus who has come to take Polyxena to her death (234 ff.), ${ }^{54}$ but Odysseus is unmoved. Hecuba now turns to Polyxena herself and

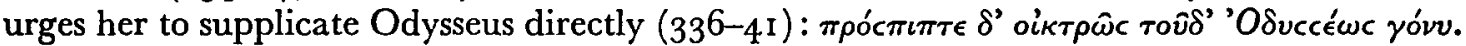
But Odysseus has taken counter-measures. Polyxena's first words to him (342-5) are:

51 The phrase in Greek would, of course, be a

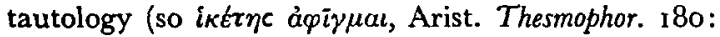

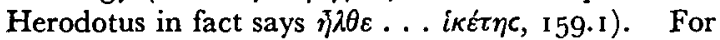

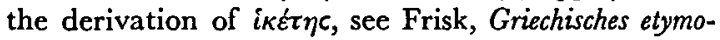
logisches Wörterbuch s.v.; Chantraine, Dictionnaire etymologique de la langue grecque s.v. i $\kappa \omega$. The etymology is doubted by Kopperschmidt, Die Hikesie $5 \mathrm{n} . \mathrm{r}$, who quotes E. Fraenkel's suggestion of a root $\iota k-=$

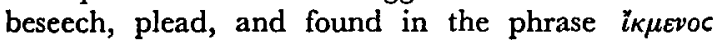
ovpoc, but this last is itself too obscure a phrase to yield any light. The traditional etymology is supported and discussed by Benveniste, Vocabulaire des institutions indo-européennes ii 252-4, who suggests that the distinctive sense of the root $i \kappa$ - is that of 'reaching' or 'gaining'. Paktyes is a suppliant in

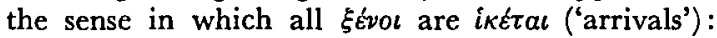
Herodotus gives no description of the ritual elements of his iketela at Kyme. On the relation between strangers and suppliants, see below, Section 5, pp. $90 \mathrm{ff}$.

52 For the theme of 'quem deus vult perdere', see
Dodds, Greeks and the Irrational $38 \mathrm{ff}$; K. Deichgräber, Der listensinnende Trug des Gottes (Göttingen, 1952) $108 \mathrm{ff}$. With Aristodikos' attempt to force a different response from the oracle, compare Herod. i 91.4

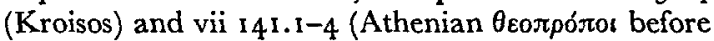
Salamis: another case of supplication!) ; J. Kirchberg, Die Funktion der Orakel im Werke Herodots $32 \mathrm{f}$; $\mathbf{H}$. Klees, Die Eigenart des gr. Glaubens an Orakel und Seher $82 \mathrm{f}$.

53 The commentators cite the obvious Biblical parallel, Matthew xxvii 6.

54 That it is 'figurative' (see $275 \mathrm{ff}$. for the language of supplication) is suggested by the length both of Hecuba's plea and of Odysseus' reply, by the extravagance of the apostrophe at $286 \mathrm{ff}$., and above all by

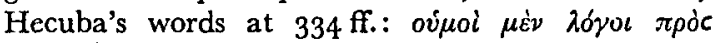

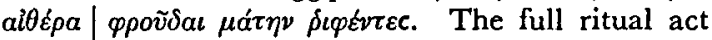
in this scene is constantly expected, constantly deferred and in the end does not take place, since Polyxena scorns to supplicate. 


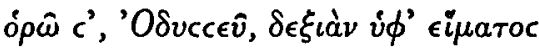

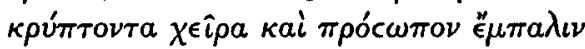

стрє́́)

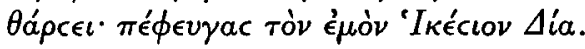

He has removed from reach and threat of physical contact his hand and face: he is playing

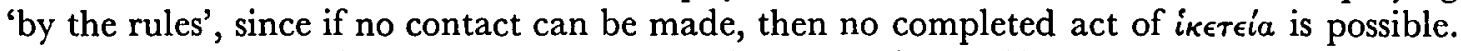
Later in the same play Agamemnon similarly steps aside as Hecuba works herself up to complete her act of supplication ( $8 \mathrm{I} 2 \mathrm{f}$.)..$^{55} \quad$ It is indeed in the world of fifth-century tragedy that the presentation of supplication as the ritual culmination of a process of appeal achieves its full measure, and I turn now to tragedy in an attempt to suggest something of that effect, for the act of supplication is one of those 'significant actions' around which, as Oliver Taplin has recently demonstrated, much of the dramatic force of Greek tragedy is aligned..$^{56}$

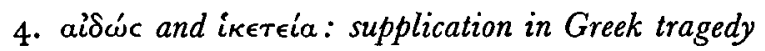

I turn first to two Euripidean scenes out of many which hinge about acts of supplication. The first is the scene between Kreon and Medea (Medea $324 \mathrm{ff}$.). Kreon, sharp and peremptory, has uttered his royal order of immediate exile-and his determination to see it executed before he leaves (27I-6). Medea questions and pleads: she builds a developed rhetorical case around the falseness of reputation and the absence of any quarrel between herself and Kreon. But she makes no progress: Kreon's mind is unchanged, his decision firm (316-23). Stichomythia begins; and Medea resorts to 'figurative' supplication,

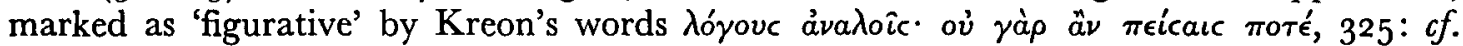

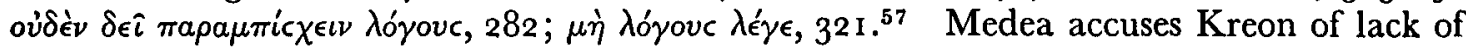
aiow'c before her pleas, but maintains her pressure in a shifting sequence of thrusts: apostrophe, gnome, apostrophe again. But all fail, and Medea utters what appears to be a half-resigned acceptance of her fate (334). Yet the tone of Kreon's replies becomes steadily more intense and strident; and then, suddenly, Medea promises to obey, and in the same line reverts to the language of supplication, this time in a 'completed' tense: $\phi \epsilon v \xi \circ v$ ' $\mu \epsilon \theta$ '.

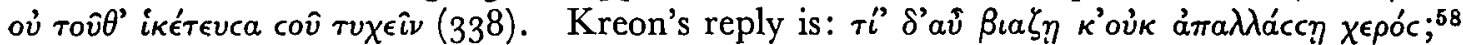
Medea's new plea, for twenty-four hours respite, is uttered in an eight line speech, and Kreon in his reply at once gives way. And yet-he is, very uncharacteristically for a

s5 Hecuba's words at $753 \mathrm{f}$. constitute 'figurative' supplication only, as the whole slow-built crescendo of the following stichomythia, ending with their repetition at 787 , makes clear; it is only with the renewed sweep of rhetorical crescendo that begins at 798 and is broken off suddenly at $8 \mathrm{I}$, that Hecuba prepares for the ritual act. 812-13 mark the low point of the scene: a new crescendo at $835 \mathrm{ff}$. takes Hecuba to the moment of touching Agamemnon's hand at $84 \mathrm{I} \mathrm{ff}$; her completed supplication is acknowledged by Agamemnon at 851. The whole scene between Hecuba and Agamemnon has the moment of supplication as its centre-piece. A possible parallel for Agamemnon's movement away is to be found at Orestes $632-3$, though there Menelaus' movement is construed by Orestes as an agony of indecision. Orestes' earlier supplication ( $3^{82} \mathrm{ff}$.) was 'figurative' : see di Benedetto's note on 383 .

so Oliver Taplin, 'Significant actions in Sophocles' Philoctetes', GRBS xii (1971) 25-44, esp. 'the small stage actions-arrival, departure, embracing, separa- ting, handing over objects-slight deeds such as these take on, in their context, greatly magnified significance and become the embodiments of tragedy' (25): I would add the act of supplication to these 'slight deeds'.

57 Further evidence for the 'figurative' nature of Medea's first supplication is to be found in the

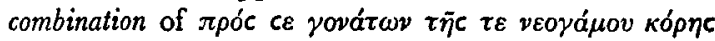
(324): compare Hector's supplication of Achilles (Il. xxii 338 ; n. 42 above).

${ }^{58} \chi \varepsilon \rho o ́ c$ is Wilamowitz' emendation for the MSS reading $\chi$ Oovóc. It is rejected by Page and not mentioned in his apparatus, yet it is surely right. The emendation was suggested to Wilamowitz (Analecta Euripidea $247 \mathrm{f}$.) by the corresponding passage Hippolytus 324 ff. (on which see below, p. 86): Wilamowitz saw, as subsequent commentators have not always, that the act of supplication was the kernel of this scene, and that in this respect the two scenes, in Hippolytus and Medea, were parallel: see also O. Regenbogen, Eranos xlviii (1950) 32. 
rúpavvoc in Greek tragedy, conscious of having made a wrong decision in changing his mind. ${ }^{59}$ What then has happened?

Medea's second apostrophe is to Zeus, the god of suppliants, and Kreon's reply tells her

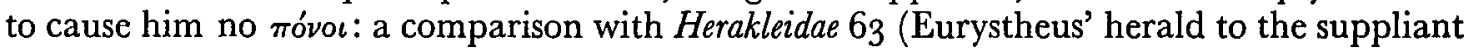
children of Herakles) suggests that the reference is to the need to drag her away: in uttering her appeal to Zeus to witness, Medea moves towards Kreon, who at once realises her intention. Medea's next utterance temporises, but she is still advancing: hence Kreon's

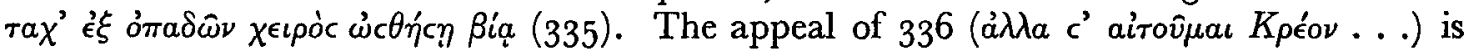

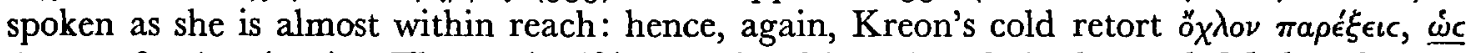
Éoıkac, $\dot{\omega}$ rovaı (337). The act itself is completed in 338 and simultaneously Medea changes the very substance of her plea: it is this combination of ritual act and diplomatic léger-demain which forces acceptance from Kreon. His aioúc (aidoúnevoc: 349 ) inhibits refusal: there is no further argument, and Medea can now relax into longer utterance, since the ritual gesture has locked Kreon into a situation from which there is no escaping without an act of physical violence against Zeus' suppliant. Thus here the ritual act is the climax towards which this brief scene moves in crescendo and which acts as the catalyst for the tensions which dominate the stichomythia: with the completed act the stichomythia is over. ${ }^{60}$

The Medea-Kreon scene is brief and in a sense peripheral: it functions as no more than a lever to break up the log-jam of the opening impasse of the play, and to get the action of Medea's revenge in motion. Though in some respects its function is similar, the scene in Hippolytus between Phaidra and the Nurse comes closer to the substance of what the play is about, and Euripides gives it correspondingly greater sweep. Before the beginning of the stichomythia ( $3{ }^{\mathrm{I}} 3 \mathrm{ff}$.), the Nurse's attempts to penetrate the defences of Phaidra's aid ' $^{61}$ have all failed. In the anapaestic prelude to the scene contact has been almost non-existent; after the gnomic coda to the anapaests ( $252 \mathrm{ff}$.) and the following brief dialogue with the chorus $(267-87)$, the Nurse attempts sustained persuasion (288 ff.), without success (304 f.:

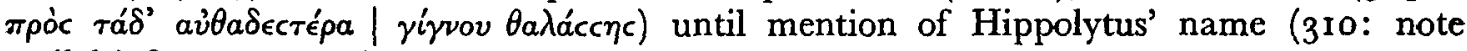
antilabe) forces a reaction. Stichomythia now begins, but in the tense move and countermove of stichomythia Phaidra continues to parry every suggestion; then, suddenly, the Nurse falls at Phaidra's knees and takes her hand (324).$^{62}$ Phaidra pleads with the Nurse

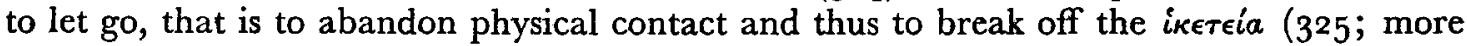
strongly still 333): there is a moment in which a tense equilibrium prevails; then Phaidra gives way: ai $\delta$ ẃc prevents rejection of the suppliant (335).63 An evasive forward movement in the stichomythia now begins, with Phaidra volunteering, not defending: the stichomythia is not complete until, with the second mention of Hippolytus' name (352, again with antilabe), the truth is out. Here, then, the ritual act is again the centre of a scene of tense and strained deadlock: as in Medea it leads within the larger frame to the breakthrough of

59 On changes of mind in Greek tragedy, see Bernard Knox, GRBS vii (1966) 213-32 (on Medea, 222-5).

${ }_{60}$ The stichomythia is most recently discussed by E.-R. Schwinge, Die Verwendung der Stichomythie in den Dramen des Euripides 68-70: he analyses the scene without reference to the act of supplication, and sees its development in purely psychological termsMedea 'realises' that she cannot achieve what she has been attempting; this 'realisation' is then acted upon and she reduces her demand to a minimum: hence her success.

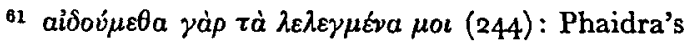
first connected utterance after her return to awareness.
62 The verbal obscurity of 324 , which has led to a variety of interpretations (see Wilamowitz, Analecta Euripidea 247: it must mean, so Barrett ad loc., 'it will be at your door that my failure will lie'), would be palpably less obscure in performance, since it is with these words that the Nurse completes the ritual act of iketela.

${ }^{63}$ For aid $\dot{c} c$ before a suppliant see the passages collected by Barrett on 1l. 333-5 and add, for example, Od. v 447 ; vii $165=181$; ix 269 ; xv 373 ; xvii 578 ; Aesch. Suppl. 28, 192, 194, 345, 362, 455, 478 f., 49 1, 641; Eur. Hecuba 286, 806; Herakles 556; IT 949: Satyros showed himaself ảvan $\delta$ cratoc in using force against the suppliant Theramenes (above, p. $8_{3}$ ). 
the forces pent up in the opening movement of the play, but here it is seen, as it were, as the point of balance in a stichomythia of shifting ambiguities and pressures. ${ }^{64}$

We have seen in these examples the constant association of ideas between supplication and aiocic: as a link between supplication face to face and supplication in Greek tragedy in its sanctuary form, it will be helpful to look more closely at this association and at what it can tell us of the underlying significance of the ritual and the nature of its force. The

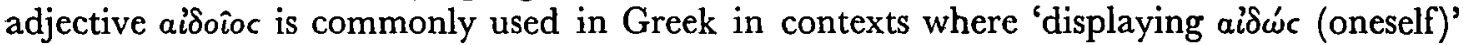
seems a natural English translation, but it is equally used in others where 'appealing to, causing, activating ai $\delta$ ẃc (in another)' seems more natural: and in many contexts on an open-minded reading a sharp distinction will seem hard, if not impossible, to draw. It seems plausible to suggest, then, that here we have a member of that not inconsiderable class of Greek words where reciprocity of usage implies reciprocity of behaviour and attitude in the situation of which the word is used: the feeling of aiswe, we may say, is common to both parties in the encounter, or, to put the matter more generally, is characteristic of the encounter itself. It is indeed of encounters that the word and its cognates are most commonly used: thus, for example, of encounters between men and women, ${ }^{65}$ or between children and their elders, or more relevantly to the subject of this present paper, of encounters between iќ́tal and those who receive them. ${ }^{66}$ If we look at the word in this way, we shall be the less surprised, for instance, to find not only the Argive king but also Zeus himself described as aiooioc in Aeschylus' Suppliants (491, 192); the wind that brings

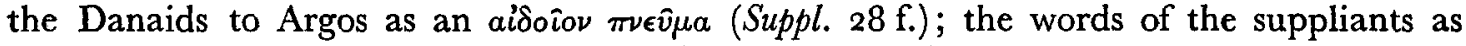

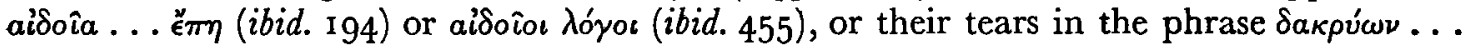

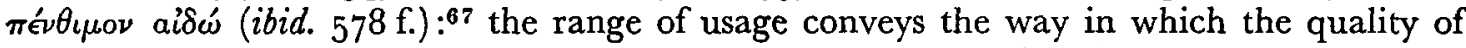
ai $\delta$ we is felt as emanating from the situation in which a suppliant is encountered, and as characterising all parties to and aspects of that encounter. ai $\delta$ ćc is equally the mark of the due reaction of the receiver of suppliants to the suppliants themselves (Suppl. 362,641 ), to the sacred ground they occupy (ibid. $345 \mathrm{f}$.), and to the anger of Zeus that lies in wait for one who rejects them (ibid. 478). Something of the same range of usage, though characteristically without the same metaphorical intensity, can be found equally in Euripides: aioúc commonly before a suppliant (Herakleidae 101, Hec. 286, 806; I.T. 949; I.A. 1246); before the suppliant's prayers (Med. $3^{26}$ ) or hand (Hipp. $3^{25}:$ cf. I.A. $83^{1-4}$ ) or in the suppliant's eyes (I.A. 994; cf. Herakles I 198-1 20I). Thus ai $\delta$ '́c represents, more than any other quality, the characteristic feeling-tone of the supplication situation.

Now aisúc is above all a word used in Greek to describe inhibition feelings. If I may borrow an analogy from African ethnography, there is an evident and close analogy with the Nuer word thek, translated by Evans-Pritchard as 'respect' and described by him as an 'interdictory concept':68 'Thek has . . . in all its contexts of usage a sense of deference, constraint, modesty or shyness, or a mixture of these attitudes. It seems often to carry as part of its load of meaning a feeling of embarrassment which is entirely lacking in the ordinary behaviour of the Nuer towards persons and nature. The behaviour associated

\footnotetext{
64 There is a close connection between face to face supplication and stichomythia, especially in Euripides: the connection stems from the peculiar dramatic quality of stichomythia, which serves to present moments where forces in opposition meet in an ambiguous tension and a breakthrough is always a felt possibility. It is precisely because of their increasingly ambiguous tone and atmosphere that stichomythia plays an ever larger part in Euripides' later plays. The scene between Phaidra and the Nurse is discussed by Schwinge, Die Verwendung der Stichomythie 182-4.
}

65 See, for example, Ebeling, Lexicon Homericum s.v. aidoioc 1 (b) and (c); Lexikon des frühgriechischen Epos s.v. aidoīoc B. I.a. $\beta, 2 . \mathrm{a}, \mathrm{b}$ and c.

o6 See Lexikon d. frühgr. Epos s.v. aldoĩoc B.1.a, $\gamma$;

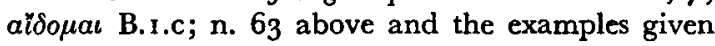
below.

67 With Aeschylus' usage we may compare Empedocles' phrase, of Akragas, $\xi \varepsilon l v \omega \nu$ aidoĩo، $\lambda_{\iota \mu \varepsilon ́ v \varepsilon c}(f r .112 .3 \mathrm{DK}$ ).

68 E. E. Evans-Pritchard, Nuer Religion 177-83. 
with it is formalistic and includes always avoidance and absention ... Failure to show respect where there is a thek relationship is more than a breach of decorum. It entails to a greater or lesser extent religious sanctions.' ${ }^{69}$ So too with ai $\delta$ '́c: whether it be the inhibiting sense of being under the gaze of one's peers on the battlefield, ${ }^{70}$ or the abashed, 'shamefaced' demeanour of the poor man or the woman or child, ${ }^{71}$ it is characteristically of the constrained rejection of some line of (usually aggressive) behaviour, possible under other circumstances or to another agent, that ai $\delta$ ćc words are used. True, ai $\delta \dot{c} c$ words occur also from time to time in connection with $\xi^{\prime} v^{\prime}{ }^{2},{ }^{72}$ but there is, I think, a detectable and crucial difference. The characteristic motive that impels a man to receive a $\xi \dot{\epsilon} v o c$ is positive: it is the thought of the honour and advantage that will accrue to him by so doing: in this respect Euripides' Admetus is a paradigm case. ${ }^{73}$ The relationship is one of the mutual conferment of honour and esteem: both men treat one another as peers, and both are proud and confident, and emphasis on feelings of inhibition is correspondingly less. In a supplication situation, on the other hand, consciousness of the great imbalance of status and honour brings into play feelings of constraint and a less self-confident pattern of demeanour and behaviour, ${ }^{74}$ accompanied at times by an atmosphere of strain and embarrassment: hence the association in Greek sensibility between the behaviour of suppliants and that of women and children. It may be helpful here to compare, however distantly, Pitt-Rivers' distinction between the 'gypsy' and the 'honourable' beggar in Andalusia: the former begs by 'flattery, fawning, inspiring pity and using any conceivable line of moral blackmail to extract alms . . . This method is used by habitual beggars, gypsies and persons who have lost their shame', whereas the 'honourable' beggar 'is a man who would be ashamed to beg in his own pueblo, but begs because he is travelling in search of his living and has run out of money. He asks for food or alms or work, and he asks for it quietly and proudly, basing his claim to help upon a duty that is thought to exist everywhere-that he who has must give to him who has not. Such a beggar tends to be very shy and to stand at a distance waiting to be asked what he wants. He does not sacrifice his pride willingly and he feels troubled by it in such a situation. At times such people cover up their shyness by a brusque and insolent manner as if to deny that they are asking a

oo Evans-Pritchard, op. cit. 181 : cf. also ibid. 79.

70 See, for example, the repeated Homeric formula for staying a rout: al $\delta$ ẃc, 'Apyeio (Il. v 787 ; viii 228 ; xiii $95 ; \mathrm{xv} 502$ ) and the 'rationalisation' of this appeal: $v 529 \mathrm{ff}$. $=x \mathrm{xv} 6 \mathrm{I} \mathrm{ff}$. The fullest and most perceptive treatment of the concept is still C. E. Frhr. von Erffa's $A I \Delta \Omega \Sigma$ und verwandte Begriffe (Philologus, Supplementband 30.2), 1937; on supplication, see esp. I 3 f., 86-9o, i i 3 f., I 35-9, i 94 .

${ }^{21}$ For example, Od. xvii 578; Hes. Works and Days $317 \mathrm{ff}$. (poor men); Od. iii 14 with $22 \mathrm{ff}$. (the young); for women, see n. 65 above; Eur. El. $34^{1}$ ff., Phoen. $88 \mathrm{ff}$. with $\mathrm{I} 93 \mathrm{ff}$. and for al $\delta \omega \mathrm{c}$ generally, Hipp. 385 on which see, most recently, D. Claus, Yale Class. Studies xxii (1972) $223 \mathrm{ff}$.

72 For example, Od. viii 544 ; ix $270 \mathrm{f}$. (together with iketra ); xix 191, 316; cf. Il. ix 639 f.; Od. xxi $25 \mathrm{ff}$.

${ }^{73}$ Alcestis $55^{\mathrm{I}} \mathrm{ff}$. For the honorific and competitive character of hospitality to a $\xi$ ćvoc, compare the attitude to hospitality of the Sarakatsani: 'Men do not often visit kinsmen of low prestige, since such association only draws attention to a relationship which is best forgotten: on the other hand, they take every opportunity to pay a call on a kinsman of position and repute to cultivate a relationship that is a source of possible support in future misfortune, and, of itself, brings a measure of vicarious prestige ... Indeed, the number of visitors that a family receives is generally a reliable index of its reputation. It is always known in the neighbourhood when a family has had guests; their quality, relationship, and the possible reasons for their visit are debated in detail by the other families. In hospitality ( $\varphi\left(\lambda_{0} \xi \varepsilon v i \alpha\right)$, a virtue in which the Sarakatsani believe they are naturally pre-eminent, there is always a strong element of competition.' (J. K. Campbell, Honour, Family and Patronage: a study of institutions and moral values in a Greek mountain community 299 f.).

${ }^{74}$ Note, for example, the well-established connection between aibúc and the eyes: the characteristic demeanour of the aldoioc is the abashed down-casting of the eyes: $c f$. Sappho $f r .137$ LP, Aesch. fr. $242 \mathrm{~N}^{2}=420$ Mette, fr. $355.20 \mathrm{ff}$. Mette, Eur. Hipp. 244 ff., Hec. $968 \mathrm{ff}$., Herakles $198 \mathrm{ff}$., I.A. $85 \mathrm{r}, 993 \mathrm{f}$., $\mathrm{r} 34 \mathrm{I}$ ff., and contrast I.A. $378 \mathrm{ff}$., Ar.

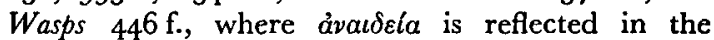
unflinching gaze of the eyes; more generally, Theognis 83-6, Hom. Hymn Dem. 194, 214-16, Eur. fr. 75 Austin $=457 \mathrm{~N}^{2}$; Arist. Rhet. ii $\mathrm{r}_{384^{\mathrm{a}}} 33 \mathrm{f}$., and L. Malten, Die Sprache des menschlichen Antlitzes im frühen Griechentum, esp. 22 f., $24,29$. 
favour which they cannot repay.' 75 The proud distance of the 'honourable' beggar recalls the reserved and distant approach of the Homeric $\xi^{\prime}$ tvoc which expresses itself by his standing in the portico of the palace, waiting to be invited to share hospitality, ${ }^{75^{2}}$ while the fawning and flattery of the 'gypsy' beggar is closely allied to the self-abasement of the iкérnc: the

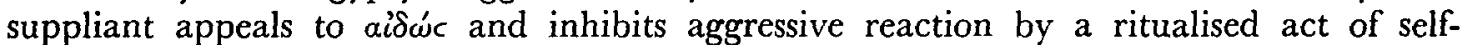
humiliation. It is in this 'interdictory' sense, to use Evans-Pritchard's term, that suppliants are aißoîot.

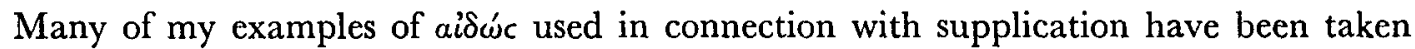

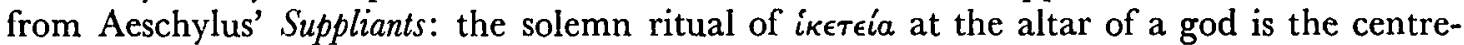
piece, not only of this play and of Euripides' play of the same name, but also of a whole series of scenes in other plays, especially of Euripides. ${ }^{76}$ In this more public situation it is regularly ai $\delta \dot{c} c$ that inhibits rejection of the suppliant, ${ }^{76 a}$ and here too, just as in supplication face to face, the ritual is a transitional one, the state of the suppliant of its nature a temporary state. But in this case the appeal of the suppliant is to be received into the protection of whoever, whether individual or community, is kv́p Thus the Argive king in Aeschylus distinguishes between suppliants who sit at the hearth

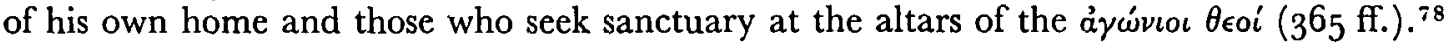

The solemn and ceremonial progress of Aeschylus' Suppliants is indeed our best evidence for the impact of such public supplication in the mid-fifth century. ${ }^{79}$ The daughters of Danaos are iкétaı in the full sense: outsiders, though in their own claim kinsmen of the Argives, they have come across the sea and in the parodos of the play (1-1 $75 \mathrm{ff}$.) arrive to take up their place in the sanctuary offered by the altars of the assembled gods. When the Argive king appears, he accepts, after due interrogation, the claim of the Danaids to be of Argive ancestry $(325 \mathrm{f}$.), but in what follows it is their status as suppliants that is at stake

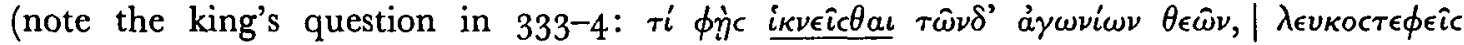

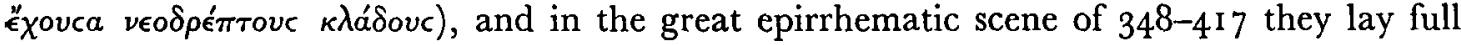
weight on the anger of Zeus if their supplication is rejected (see especially $38 \mathrm{I}-6$ and the king's recognition of this, $44^{1} 3^{-16}$, and again at $47^{8-9}, 6$ I $5 \mathrm{f}$.). Their claim is for protection, and to grant their claim is tantamount to receiving them within the community. In the outcome the king agrees to allow Danaos to put his case for such reception to the $\lambda \epsilon u$ c of Argos. ${ }^{80}$ Thus at 506, as Schlesinger has pointed out, the supplication of the Danaids is technically at an end: they have found a $\pi \rho o ́ \xi \epsilon \nu o c(49 I) .{ }^{81}$ And so when Danaos leaves

${ }^{75} \mathrm{~J}$. Pitt-Rivers, The People of the Sierra 60-1: the 'gypsy' beggar is the 'cara dura' (hard-faced) or 'sin verguenza' (shameless one). Compare further the 'gypsy' beggar's use of the honorific title, 'Senorito': 'Senorito is used as a term of affectionate respect with reference to or in addressing a young adult of superior status . . gypsy beggars used it to any person dressed in urban dress, for the attribution flatters. Using it carries an implication of subservience.' (Pitt-Rivers, ibid. 74.)

75a See below, p. 91.

${ }^{70}$ On Euripidean 'altar-scenes', see H. Strohm, Euripides: Interpretationen zur dramatischen Form, chap. I, esp. 17-32; Kopperschmidt, Die Hikesie 129-213, with further references, pp. 6-9; Anne Burnett, Catastrophe survived, esp. $76 \mathrm{ff}$., I 19-22, I $31 \mathrm{ff}$, $157 \mathrm{ff}$.

70. For Aeschylus, Suppliants, see above n. 63 and p. 87 .

7 On the connection between supplication and sanctuary, there is still no better account of the Greek evidence than Schlesinger, Die gr. Asylie, esp. 28-52. The Greek term for sanctuary is properly $\varphi v \xi \xi^{\prime} o_{\nu}$ (first in Od. v 359); for öpo marking the boundaries of iepá, see L. Robert, Hellenica vi (1948) 33-8: the earliest from Corinth, fifth-century.

${ }^{78}$ See below, n. $100^{a}$; for the áyóvıo $\theta \varepsilon o i$, see Fraenkel on Agamemnon 5 13: like the Plataians at Athens (Herod. vi 108.4), the Danaids take refuge at the altar of the 'assembled gods'.

79 See especially, Schlesinger, Asylie 39-47; Kopperschmidt, Die Hikesie 54-73.

80 For $\delta \varepsilon^{\prime} \chi \varepsilon c \theta \alpha \iota$ as the object of the Danaids' supplication, see 27 ( $\left.\delta \varepsilon^{\prime} \xi \alpha c \theta^{\prime} i \kappa \varepsilon \dot{\tau} \eta \nu\right), 219$, and com-

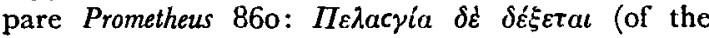
Danaids), if the MSS. reading there is sound. Further, the case of the Epidamnian suppliants at

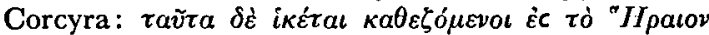

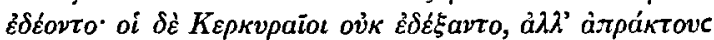

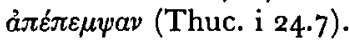

${ }^{81}$ Cf. 239, 419, 919 f.; P. Oxy. 2161, col. 1, $4=$

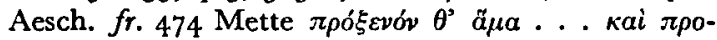
лрактора (Diktyoulkoi : Silenus offers himself to Danae, who is a $\xi \varepsilon \eta \eta)$. 
sanctuary to go into the city and make his plea to the Argive people, he is given an escort to ensure his safety (492-50I): he has let go of contact with what is iepóv and entered upon a mission which involves contact with the secular. The Argive people decree to Danaos and his daughters the right of $\mu \in \tau o$ kia (6og) and the protection of the whole community: the phase of supplication is at an end.

All this, of course, is a fifth-century Athenian vision of the progress of a supplication, and its interest lies in the way in which it presents a sophisticated, 'political' version of a primitive and ancient social institution. ${ }^{82}$ So too, for example, and even more obviously, with the supplication of the Argive mothers in Euripides' Suppliants, where sophistication, both moral and political, is taken to lengths well beyond those of Aeschylus' conception. ${ }^{83}$ Even in the dramatic imagination of Sophocles, secular, 'patriotic' and political themes mix with the ritual of supplication in Oedipus at Colonus. Nowhere else in Greek tragedy does the primitively mysterious power of boundaries and thresholds, the 'extraterritoriality' of the sacred, make itself felt with the force and precision that Sophocles achieves in the parodos of Oedipus at Colonus (especially I I 7-98). ${ }^{84}$ Yet in this play too, acceptance of Oedipus the $\xi_{\text {'́noc }}$ (1 $3,184,26 \mathrm{I}, 562 \mathrm{ff} ., 638,903,1249,1335,1501,1577$, etc.) blends with the political conception of a clash of wills and military strength between one $\pi$ ó $_{k c}$ and another. ${ }^{85}$ Nevertheless, at base and in origin, the suppliant is felt and presented as the $\xi$ '́roc, the outsider who does not fit within the categories of social existence and who thus stands, as Oedipus stands, outside the order of things. It is to this relationship between stranger and suppliant that I now wish to return for a more detailed discussion.

\section{Strangers and suppliants}

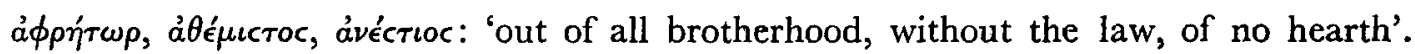
These words of Nestor ( $I l$. ix 63 ) may well serve to describe the stranger in ancient Greece. 'He who is without ties of kinship is without rights and without protection, save the protection of the gods.' 86 In a world in which the solidarity of the group is all-important, it is membership of and place within the group which confers and determines status and position on the scale of honour, and which in so doing defines the role of the individual in society. It is possession and awareness of this role (awareness on the part both of the possessor and of the other members of the group) that alone provides those key indices of expected behaviour without which the continuity and stability of society is threatened. Hence the $\xi^{\prime}$ 'voc, the outsider who does not belong, is a man without a role, that is without both rights and obligations-one who, in a fundamental sense, does not know how to behave and to whom the members of the group do not know how to behave either: from his point of view, everything is at risk and nothing can be taken for granted; from the point of view of the members of the group he constitutes an unsettling threat who cannot be 'placed' and whose behaviour, therefore, cannot be predicted. Or rather, all these things would be so,

82 The public and political language of $605 \mathrm{fr}$.

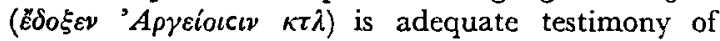
this: see especially A. J. Podlecki, Political Background of Aeschylean tragedy 45-50. Rudolf Herzog (Abhandlungen preuss. Akad., Berlin, 1928, Phil.-hist. Klasse, no. 6 , p. $3^{6}$ ), supported by Schlesinger (op. cit. 44-6), saw in iketeia the source of the Athenian system of metic-rights. That Aeschylus' dramatic imagination so construed it in Suppliants is clear: the historical question is different, but Herzog's suggestion is tempting.

${ }^{83}$ See in particular Theseus' rhesis $195^{-249}$, and the scene between Theseus and the Theban herald, 399-584.
84 On the sense of the sacredness of place in Oedipus at Colonus, see esp. John Jones, On Aristotle and Greek tragedy $218 \mathrm{ff}$.

85 References to Athens and Thebes in ródcc-terms are too numerous to list, but see in particular 2, 47, 108, 236, 432, 440,613,733,758, 772, 837, 917, 929,

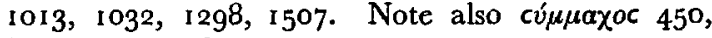
$815,1310,1376,1395$.

${ }^{86}$ See Rudolf Köstler, 'Die homerische Rechtsund Staatsordnung' in Zur griechischen Rechtsgeschichte (Wege der Forschung 45), esp. 178 , i $85 \mathrm{ff}$. 
if it were not for the 'institutionalising' of behaviour, of the role of the E'vec both as 'guest' and 'host', by the operation of what we awkwardly translate as 'guest-friendship' ${ }^{87}$ The existence of $\xi \in v i a$ reintroduces the concept of 'rules', patterns of expectation which allow coexistence between those who are not members of the same group. The rules of $\xi \in v^{\prime} a$ are all but absolute: hospitality must be offered and must be accepted, ${ }^{\mathbf{8 8}}$ and once accepted a permanent tie is created.

The Homeric poems provide a detailed guide as to the proper treatment to be accorded to the छ'́voc. When Nestor and Peleus come to Phthia on their mission of assembling the Greek army to go to Troy (Il. xi $765 \mathrm{ff}$.), they find Peleus sacrificing in the avid ${ }^{\prime}$ of his palace, and they stand quietly waiting in the $\pi \rho$ ó $\theta v p a$. Achilles (the youngest person present) ${ }^{89}$ sees them and jumps to his feet; he takes them by the hand, tells them to be seated, and puts

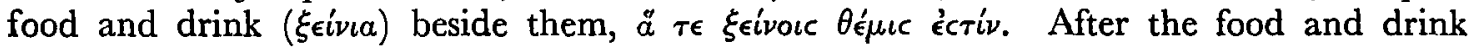
come the questions. ${ }^{90}$ This, the proper behaviour, is supported by a counter-example.

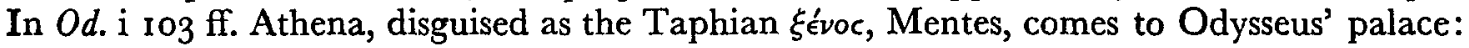
she too stands quietly waiting in the $\pi \rho o$ ó $v \rho a$ - and is ignored. The suitors are playing at $\pi \epsilon c c o i$, and drinking and eating; Telemachus is sitting among them lost in misery and thinking about his father's return. Suddenly he sees Athena, and goes straight to the $\pi \rho \theta^{\theta} \theta p a$ to take her by the hand and escort her into the palace. On seeing her, he is angry

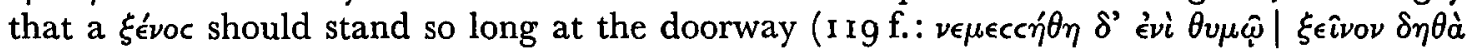

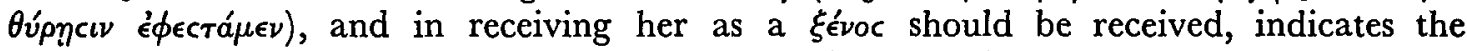
importance of conferring $\tau \iota \mu \eta^{\prime}$ upon the new arrival (note the linen cloth placed on the chair, and the footstool), ${ }^{91}$ and of diplomacy (Athena is placed at a distance from the suitors to avoid further embarrassment). Diplomacy in social relationships was always necessary in a world where insults were commonly exchanged and even more commonly seen where none, perhaps, was intended: tension may arise, and must be avoided, over questions of who should address whom first (for example, $O d$. iii $22 \mathrm{ff}$.), who should be the first to receive a mark of honour ( $O d$. iii $49 \mathrm{ff}$.), whether a challenge is within the proper bounds of conduct as between one person and another (Od. viii $\mathrm{I}_{3} \mathrm{I} \mathrm{ff}$., especially $204 \mathrm{ff}$., is an instructive example), and so on.

In all these matters the ritualising of behaviour constitutes a powerful factor in keeping the tensions of existence within tolerable limits. 'The detailed explication of ritual prescriptions serves to reduce anxieties, doing this in all the ways accomplished by formal rules ... Knowing exactly what is required in each area of life enhances the sense of control, for the things that ritual requires can be done. ${ }^{92}$ At one end of the spectrum of social encounter, we shall describe these things to ourselves as a code of manners, a matter of politeness no more important than the proper way to eat peas with a fork. But it is important to note that the significance of the ritual increases in direct proportion to the sanction to be imposed upon a breach of it: the greater the sanction, the more awesome the authority which stands behind that sanction, the greater the anxieties involved over the proper performance of ritual requirement. And for breaches both of the rites of $\xi \in v i a$ and

87 On 'guest-friendship', see Finley, World of Odysseus I I 4-20; Walcot, Greek peasants: ancient and modern 80; Benveniste, Vocabulaire des institutions indoeuropeennes i 92-10 I : Benveniste stresses the reciprocity of the institution and draws attention to the modern Persian word érmán ('guest', related to old Iranian Aryaman) and deriving from a root which means 'of the same race and language'.

88 Hence the reaction of Admetus to Herakles' arrival in Euripides' Alcestis.

80 Thus it is Peisistratus, not Nestor, who goes to greet Telemachus and the disguised Athena : Od. iii 36 .
90 See also Od. iii $31 \mathrm{ff}$., iv $20 \mathrm{ff}$.: each time we encounter taking by the hand, seating and offering of food and drink. For $\theta \varepsilon \dot{\mu} \mu \mathrm{c}$ in connection with the rules of $\xi \varepsilon v i a$, note also $O d$. ix 266-8; xiv 56-7; xxiv 284-6. In Pindar Ol. viii $2 \mathbf{1}-2 \theta \varepsilon \dot{\theta} \mu \mathrm{c}$ is the $\pi \alpha \rho \varepsilon \delta \rho o c$

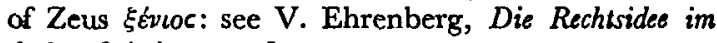
frühen Griechentum 16, 40 .

91 Compare, under different and more fabulous circumstances, Odysseus' reception by Kirke's servants: $O d . \times 348 \mathrm{ff}$.

92 A. W. Gouldner, Enter Plato $304 \mathrm{f}$. 


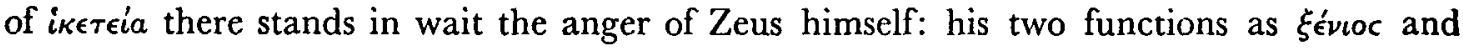
ikécıoc merge into one in such passages as Od. ix 269-7I (Odysseus to the Cyclops):

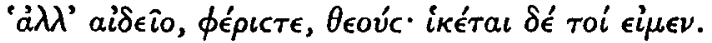

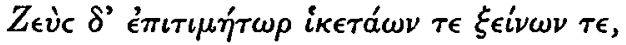

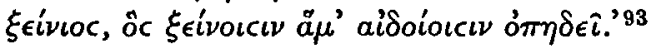

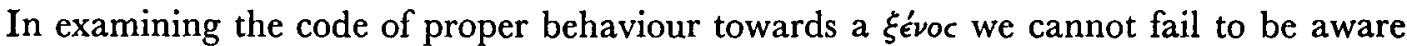
of the parallelism with the proper treatment of a suppliant: ${ }^{94}$ indeed in one sense the distinction between stranger and suppliant is a distinction of circumstance only. ${ }^{94 \mathrm{a}}$ It is this fact which explains certain linguistic parallelisms in the language appropriate to both areas of usage. It is notorious that the word $\xi^{\prime}$ voc has a range of usage which appears baffling when set against the model, say, of modern English: 'outsider', 'stranger', 'foreigner'; 'guest', 'host', 'family friend'. ${ }^{95}$ One rather mysterious passage in the Odyssey (xvi 422 f.)

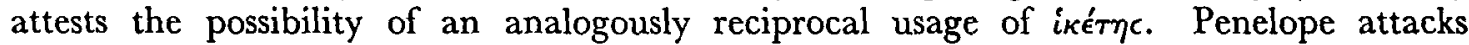
Antinoos for his attempt on Telemachus' life and connects with it his attitude to iké

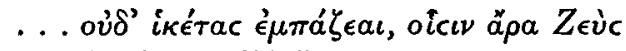

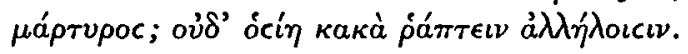

The scholja took iкétaı here to be equivalent to 'those who receive suppliants', since Penelope goes on to remind Antinoos of the fact that his father had once come as a suppliant to Odysseus, and the implication is apparent that Antinoos has inherited an obligation

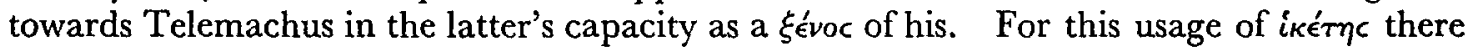
is no other evidence; yet it is clear from the use of a $\lambda \lambda \eta_{\eta} \lambda o \iota c \iota \nu$ in i 423 that the word is being

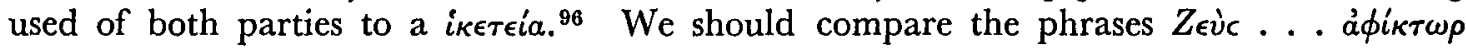
(Aesch. Suppl. 1), Z Zvòc . . . iктүিpoc (ibid. $478 \mathrm{f}$.) of Zeus as protector of suppliants. If this

${ }^{93}$ Compare the fictitious case (Od. xiv $276 \mathrm{ff}$.) of Odysseus as suppliant (279) of the Egyptian king: it is the anger of Zeus $\xi e$ ivioc (283 f.) that the king fears. Odysseus is received by Eumaeus as a $\xi \varepsilon v 0 c$ (see esp. Od. xiv $56 \mathrm{ff}$. and 388-9), but in describing his arrival and reception to Telemachus, Eumaeus

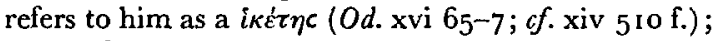

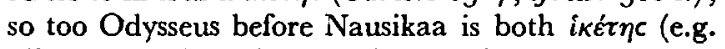
vii 292, 30I) and छ́voc (vi $206 \mathrm{ff}$.). For a later equation, see Ap. Rhod. Argonautica ii $1131 \mathrm{ff}$.

${ }_{94}$ See above, pp. $78 \mathrm{f}$.

94a The question of demarcation of roles between stranger and suppliant is one which must arise for the 'arrival' when he presents himself for acceptance by a 'foreign' community: the choice lies between waiting at the porch to be acknowledged and conducted within or crossing the threshold and adopting

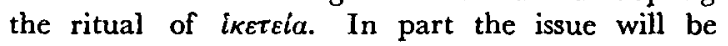
determined by the existence or otherwise of obligations previously incurred: so it is with Athena in her guise as the Taphian Mentes, as she makes clear in answer to Telemachus' explicit question (Od. i $187 \mathrm{ff}$. answering $i$ 175-7). But in addition the problem of the arrival's capacity to incur obligations will be a key factor: so again, with the presumed Mentes' economic resources (i $180-4$ ), there is no problem in accepting the offered $\xi \varepsilon \imath v \dot{t} \iota \alpha$ and promising return gifts (i 309-18). One who 'arrives' in less fortunate circumstances might well hesitate. We have seen that Odysseus seems to oscillate between the role of

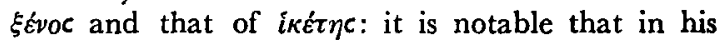
identification of himself, where he uses the word $\xi \varepsilon$ éco to describe his role, thoughts of reciprocity seem to be uppermost (Od. ix I6-18). But Odysseus' is a peculiar, even a unique, case. His first encounter with a Phaeacian, Nausikaa, takes place not in the $\pi$ ódec of the Phaeacians, but in the wilds, on 'neutral' ground, the sea-shore and the river-mouth-and he is naked. There are other signs too that in this setting feelings of inhibition prevail which would otherwise not determine behaviour: we should compare Odysseus' refusal to be bathed by Nausikaa's maidservants in the river (Od. vi 212-22) with his later bath in Alkinoos' palace (viii 449-57). With Odysseus' decision to supplicate Nausikaa on the sea-shore, we may compare his supplication of Athena disguised as a shepherd, on the sea-shore of Ithaca (Od. xiii $219 \mathrm{ff}$., especially 23I).

${ }^{85}$ For the range of usage of the root $\xi \varepsilon v$, , see H. Frisk, Gr. etym. Wörterbuch s.v. छ́voc.

${ }^{96}$ So Ameis-Hentze-Cauer ad loc. à $\lambda \lambda \eta^{\prime} \lambda o \iota c \iota v$ is in itself sufficient to rule out the suggestion of Nägelsbach, Homerische Theologie ${ }^{3} 270$, that the reference of ikérac is simply to Telemachus, as (in some vague sense) Zeus' suppliant. 


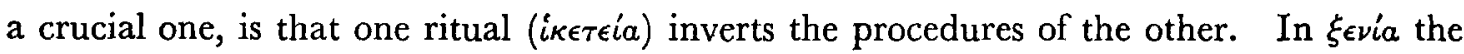
'insider' extends his protection, and the honour that such protection conveys, to the stranger. In supplication, the 'outsider' enforces a claim to the same honour and protection by a ritual procedure which enacts the total abdication of any such claim. ${ }^{101}$ We have now to

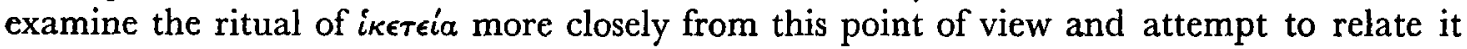
to the ordered structure of social behaviour.

\section{Supplication and the structure of behaviour}

The first and most obvious thing to note about the behaviour of the suppliant is that he goes through a series of gestures and procedures that together constitute total selfabasement. ${ }^{102}$ The suppliant comes forward with his hands empty and outstretched, ${ }^{103}$ and adopts a physical posture of inferiority towards the object of his supplication. ${ }^{104} \mathrm{He}$ stresses his own defencelessness and lack of any claim to $\tau \iota \mu \eta$ : frequently, by contrast, the suppliant exaggerates the $\tau \iota \mu \eta^{\prime}$ of the person to whom his supplication is addressed. In word and movement his behaviour indicates that he has temporarily opted out of the 'contest system' of social relationships that characterises normal behaviour between non- $\phi$ i ${ }_{0 .} .^{105}$ Thus Odysseus, before supplicating the Egyptian king, throws away his spear and removes

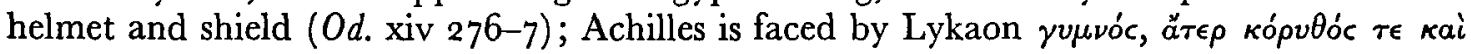

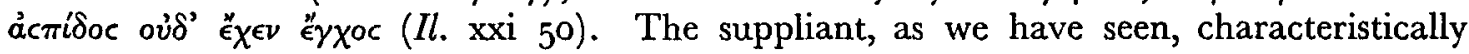
crouches or kneels, as Thetis before Zeus (Il. i 500), Odysseus before Amphinomos (Od. xviii 394 ff.), Pheretime before Aryandes (Herod. iv 165.3) or Themistokles at the hearth of

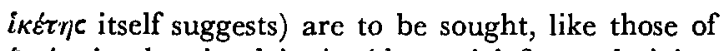
$\xi \varepsilon v i a$, in the ritual in its 'domestic' form, deriving from the arrival of an outsider at the hearth of the community, that is, in a case such as that of Odysseus on Scherie, and not, as seems frequently to be inferred or assumed, in its 'battlefield' form: the latter is merely a crisis extension, a metaphorical adaptation, of the former. The defeated warrior seeks to save his life by a ritual which implies an already accepted form of appeal to be admitted within the 'kindred' of his conqueror. The second conclusion, which I put forward more tentatively, is that public supplication at an altar is already a secondary development which is to be seen as stemming from a separation of the idea of the public altar (or hearth) as symbol of the solidarity of the community from that of the king's hearth as symbol of his personal olkoc. It is perhaps plausible to suggest that these two ideas were once single and inseparable (in the context of a Bronze Age 'palace' society) and that their separation is to be placed at some later date: thus supplication at an altar is an appeal to the community, either through a king, as in the supplication plays of Aeschylus and Euripides, or directly to the community as a political unit, as in the supplication stories of Paktyes and the Plataians in Herodotus.

101 Since the claim may, in the result, go ungranted by the human being to whom it is, directly or indirectly, addressed, while the act of abdication is complete, it is Zeus in the last resort who 'gives

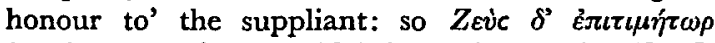

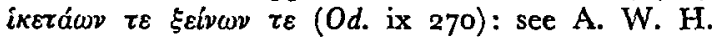
Adkins, "Honour" and "Punishment" in the Homeric poems', BICS vii (1960) 23-32, esp. $25 \mathrm{f}$.
102 For the association of ideas between supplication and (painful) self-abasement, Athena's imagined picture of Apollo pleading with Zeus for the life of Hector is instructive: $I l$. xxii 219-21, esp. ovं $\delta^{\prime} \varepsilon \bar{l}$ KEv

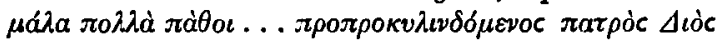
aiyıóxolo. That supplication is what Athena's words imply is suggested by the near parallel in $I l$. xxii 414 ff., where Priam appeals to the Trojans and $\lambda \iota \tau$ áveve is associated with $\kappa v \lambda \iota v \delta \delta \mu \varepsilon v o c \kappa a \tau \dot{\alpha} \kappa \delta \pi \rho o v$. For a further instance of the network of ideas connected with $\pi \rho 0 \pi \rho \sigma \kappa v \lambda(\nu \delta \varepsilon c \theta a t$, see $O d$. xvii $524 \mathrm{ff}$.

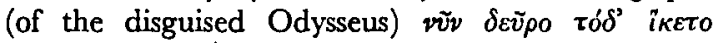

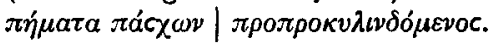

${ }^{103}$ For extending one's hands empty as a gesture of submission and respect, see Sittl, Gebärden $147 \mathrm{f}$.

${ }^{104}$ See Raymond Firth's interesting article, 'Postures and gestures of respect' in Echanges et Communications: Melanges Lévi-Strauss 188-209. It is significant that the Greek word for 'beggar' ( $\pi \tau \omega \chi \delta c$ ) means literally one who crouches, skulks or cringes: the parallel with the suppliant is exact. Compare further $\pi \tau \dot{\omega} \xi$, a 'hare' and see Frisk, Gr. etym. Wörterbuch s.vv. On crouching and bending as selfabasement and as presentation of respect, sec also Firth in J. S. La Fontaine (ed.), The interpretation of ritual: Essays in honour of $A . I$. Richards 18-19, 31-2; Esther Goody, ibid. 48-50.

105 I use Gouldner's term 'contest system', for which see Enter Plato, chapter 2. 'Temporarily', since once admitted into the group whose representative agent he supplicates, he may, within the limits of propriety for a guest, resume his competitive role, as Odysseus does on Scherie: Od. viii $165 \mathrm{ff}$. 
Admetos (Thuc. i $136.3-137.1$ ). The posture, demeanour and language of a suppliant may be compared in Greek literature to those of a slave (Eur. Hec. 249: Hecuba describing

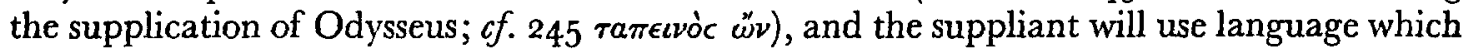
reflects humiliation upon the speaker while correspondingly according extravagant recognition to the $\tau \tau \mu \eta^{\prime}$ of the person addressed: so Hecuba to Agamemnon (Hec. 807-II, on her

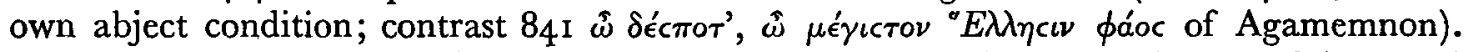
So too Themistokles, in making his plea to Admetos, stresses his own weakness and Admetos'

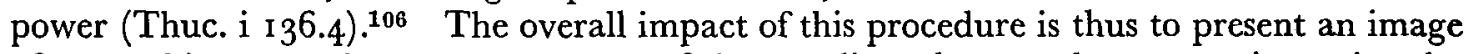
of utter abjectness: the proper response of the supplicated, as we have seen, is to give the suppliant the honour which his own behaviour has publicly disclaimed. ${ }^{107}$ 'In order that the rules of social intercourse may operate with regard to him the hostile stranger must be converted into a guest. This transformation is achieved through some ritual of incorporation which places the host and the guest outside the bounds of the rivalry that governs relationships in a neutral setting ... In the case of sanctuary the same rule may be said to apply though it is initiated by the visitor: instead of responding to an invitation to become a guest, the fugitive imposes himself as such by adopting an attitude of submission and by claiming protection in exchange for the honour which his submission conveys. ${ }^{108}$ The word 'submission' in this quocation from Pitt-Rivers well suits the Greek evidence: in reporting the supplication of the Plataians, which culminated in their sitting as suppliants at the altar of the Twelve Gods in the Agora, but which had earlier involved seeking the

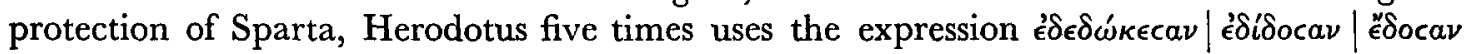
сф'́ac aúroúc: 'they gave themselves', i.e. in surrender, even though no actual conflict is involved (Her. vi I08). ${ }^{109}$ Thus, to recapitulate, supplication involves a form of selfabasement which constitutes an inversion of the normal patterns of behaviour. A normal face to face encounter between two men who are not $\phi$ i $\lambda_{0 \iota}$ involves, in ancient Greek society, a transaction of challenge and counter-challenge in a context of competing claims to $\tau \iota \mu \dot{\eta}^{\prime}$. The ritual of supplication, on the other hand, puts the new arrival 'out of play' in terms of the normal 'game' of competition, precisely because the suppliant's behaviour is an inversion of normal expected behaviour. Before the game of challenge and counterchallenge can commence the suppliant 'surrenders': the match is now a 'walk-over' and the other 'competitor' must now play according to a new set of rules.

The element of inversion of itself carries with it, as we have seen, a certain constraint and

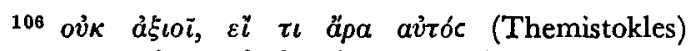

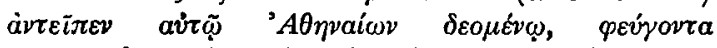

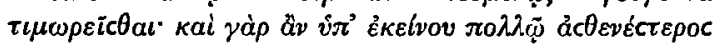

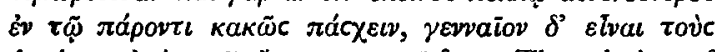

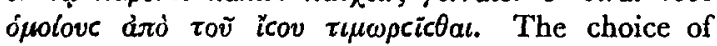
reading here lies between ác $\theta \varepsilon v \varepsilon ́ c \tau \varepsilon \rho o c$ of the second hand in $K$ or the reading of the correction in $H$

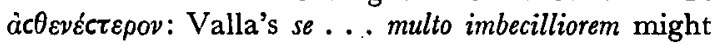
translate either. On the other hand, the reading of the medieval tradition $\dot{a} c \theta_{\varepsilon v \varepsilon c \tau \dot{\varepsilon} \rho o v}$ makes no sense ('exige de vraies acrobaties': de Romilly).

${ }_{107}$ See above, pp. $78 \mathrm{ff}$., and compare Firth, Echanges et Communications $200 \mathrm{f}$.: 'between initiator and recipient of such gestures (of respect) there is mutual interaction. The common pattern is for one who has been the recipient of nose-to-knee pressing to lift up the head of the other person and then press nose to nose. This is what the Tikopia describe as 'making the face good' (fakamatamata lavi)... A chief too likewise lifts up the head of a man who has pressed nose to his knee that they may press nose to nose. So a respect gesture in acknowledgement of
\end{abstract}

superior status which is relevant to one situation may demand an equalisation gesture in acknowledgement.'

108 Julian Pitt-Rivers, 'Women and Sanctuary in the Mediterranean', in Echanges et Commutrications: Mélanges Lévi-Strauss 862-75 (quotation taken from p. 865). See also his earlier article 'The Stranger, the Guest and the hostile Host', in Contributions to Mediterranean Sociology (1968) I $3-30$ (a French version appeared in Les Temps Modernes, no. 253 (June, 1967) 2153-78, under the title 'La loi de l'hospitalité').

109 Compare the same expression used of the suppliant slave to Herakles at his $\tau \varepsilon$ revoc at the Nile delta: Herod. ii I I3.2. Gobryas supplicates Cyrus

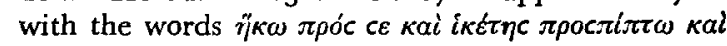

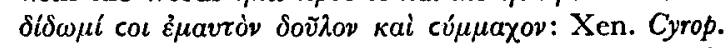

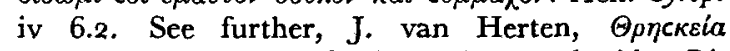

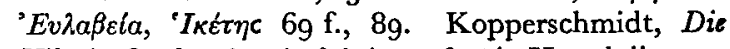
Hikesie I 8 takes éavròv $\delta \iota \delta o v ̀ c ~ \tau \tilde{\varphi} \theta \varepsilon \tilde{\varphi}$ in Herod. ii 113.2 to imply participation in the god's strength (Kraftquelle), but the analogous language used of the Plataians clearly indicates that submission is what is implied. 
emotional charge for all those participating under any conditions. But when, as must often occur in the case of supplication, the encounter between suppliant and supplicated takes place in a context dominated by the prior shedding of blood by one party or the other, this emotional charge may reach almost intolerable levels. The encounter between Priam and Achilles in Iliad 24 is a case in point. Priam goes to Achilles as the direct result of an order conveyed from Zeus himself (xxiv $146 \mathrm{ff}$. $=\mathrm{I} 75 \mathrm{ff}$; f for the status of suppliant, $c f$. $158=187$ ). The full emotional shock of what Priam is to do is conveyed not merely by Priam's explicit words in 11. 503-6:

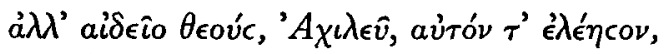

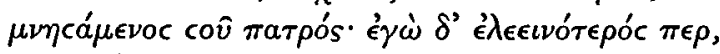

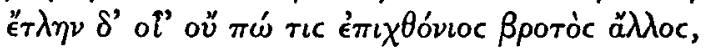

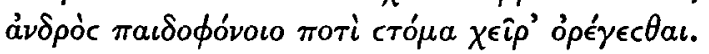

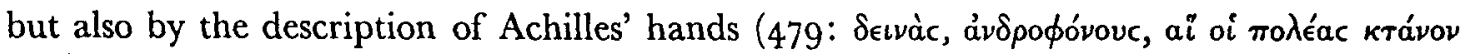
viac), where the concentration on the hands as independent agents focusses the emotional tension on the central gesture of Priam's supplication-and perhaps above all by the remarkable simile which plays a crucial part in forming the emotional tone of this scene $(480-4)$ :

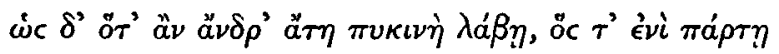

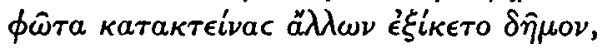

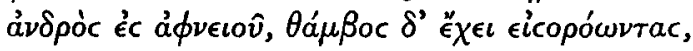

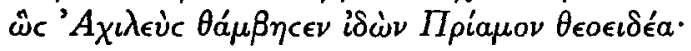

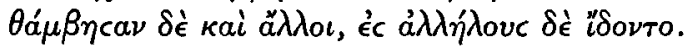

The inversion, in one central respect, as between simile and event, ${ }^{100}$ of the roles of Priam and Achilles (it is Achilles, not Priam, the supplicated, not the suppliant, who has shed blood) exactly parallels the element of inversion in Priam's behaviour and embodies the monstrous tension of the moment. ${ }^{111}$ At an altogether lower emotional level, Odysseus' supplication on Scherie is received, as we have seen, with a long silence (Od. vii ${ }_{54} \mathrm{f}$; $c f . \mathrm{I} 6 \mathrm{I})$. For until the suppliant is received, with the appropriate bestowal of honour, the world is upside down.

But so far this description and analysis of the significance of the act of supplication has taken account only of those elements in the procedure of the act which relate to the suppliant himself and which embody his image of himself as a creature without claim to $\tau \iota \mu \eta^{\prime}$. We must now consider the act and the gestures involved as they affect the person supplicated. As we have seen, it is characteristically to knees, chin and hands that the suppliant's gestures are directed. R. B. Onians has argued persuasively that these parts of the body in particular are sacred and are thought of as the seat of the 'life-stuff', the physical strength and the sexual and reproductive power of a man. ${ }^{112}$ Why were these

110 For inversion of roles between simile and event in Homeric similes, compare $I l . \mathrm{v} 554^{-60}$ (Trojan victims compared to marauding lions killed by humans) and, less closely, $O d . v 43^{\circ}-5$.

111 It does not seem to have been remarked that this simile, with its peculiar sense of the social, and perhaps religious, tension involved in a face to face encounter with one who has shed blood, deserves to be set against those Homeric passages so often quoted to establish the absence of a sense of 'pollution' in the Homeric world: see Dodds, Greeks and the Irrational 35 f. and 54 f. (nn. 39-4I); Lloyd-Jones, The Justice of Zeus $70 \mathrm{ff}$. As a further index of the tension of the moment, note Achilles' leaping up and out of the hut $\lambda \varepsilon \dot{\omega} \omega \ddot{\omega}(572)$.

112 See the passages cited above, n. 14 and for the hand, add Onians, Origins $198 \mathrm{n}$. I. We have seen that reference to the hand in supplication is relatively rare (above, p. 77): in the case of Priam and Achilles the explanation might lie in the special significance in this context of Achilles' hands, but $c f$. also Odysseus' hiding of his right hand in a supplication context (Eur. Hec. $34^{2}$ f.: see above, p. 84 ). For the symbolic role of the knees in birth and adoption, note the vases showing the new-born Athena standing on the knees of Zeus (A. B. Cook, Zeus iii 681-5) and compare 
parts of the body in particular the targets of the suppliant's ritual touch? Two interpretations of the symbolism of the act immediately occur, not necessarily mutually exclusive. One is that the vital power of the supplicated is to be thought of as flowing into the suppliant; the other, that the parts involved, as the seat of a man's life-stuff are 'tabu', his most vital, most vulnerable and most closely guarded parts, and that the gesture of touching them brings the suppliant into symbolically aggressive, yet unhurtful, contact with what the supplicated most seeks to protect. The first of these interpretations is perhaps supported by the analogous case of contact with the god's altar or statue, where we might reasonably guess at a flow of the power of the sacred from god to suppliant. ${ }^{113}$ The second interpretation receives support from a further consideration of the function of the hearth in acts of supplication. We have seen contact with the hearth in connection with Odysseus' supplication on Scherie (Od. vii 153 : note also 248 , where Odysseus refers to himself as ét'́ctioc) and with Themistokles' supplication of the Molossian king, Admetos (Thuc. i 136.3 ), and we should probably add the case of Telephus: Telephus takes refuge at what is usually described as an altar, but which, since it is rather to be thought of as inside Agamemnon's palace, is probably to be taken as the hearth. ${ }^{114}$ We should also add the association between the hearth îv ả $\phi \iota k$ áv $\omega$, Zeus and the 'table of $\xi \epsilon \nu i a^{\prime}$ ' four times repeated in Odysseus' oath (Od. xiv $158 \mathrm{f}$. = xvii ${ }_{15} \mathrm{f}$. $=\mathrm{xix}_{30} \mathrm{f}$. $=\mathrm{xx} 230 \mathrm{f}$.). The hearth is the most sacred place in the house; it is also a place to be guarded from all 'uncleanness'. Hesiod stresses that after intercourse a man should not go near the hearth (Works and Days 733-4), and the presence at it of a suppliant, while from one point of view placing him in protective contact with the inviolability of the sacred, from another constitutes an invasion of the tabus surrounding this sacred place and thus an act of mock aggression aimed at the source and symbol of the house's existence.

Another element in the constellation of ideas which associates supplication and the hearth is provided by further evidence which connects the hearth as emblem of the solidarity of the group with other forms of ritual to incorporate outsiders into the ofkoc. The hearth embodies, to quote Jean-Pierre Vernant, 'le clos, le fixe, le repli du groupe

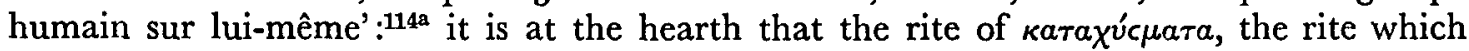
incorporates the new bride and the newly-acquired slave into the of Women and slaves, like suppliants, are outsiders who must be converted into insiders, ${ }^{116}$ and the role of the hearth in this incorporation is further recalled in the use of the verb

knee-born Dionysus (ibid. 80-9); Demosthenes' father, before his death, places his son on the knees (Eic $\tau \dot{\alpha} . .$. yóvara) of his sister's son Aphobos in token of his adoption (Dem. xxviii $15-16$ ). Compare also the same ritual in the Old Testament: $R$. de Vaux, Les Institutions de l'ancien Testament i 73.

113 So apparently Nilsson in his analogy of a flow of electrical power by 'contact', GGR $\mathrm{i}^{3} 77$; and more explicitly, Kopperschmidt, Die Hikesie 11.

114 Inside, since the whole episode in Euripides' play was in all probability reported in a messengerspeech: so Webster and Handley in Handley and Rea, The Telephus of Euripides 37. See further L. Séchan, Études sur la tragédie grecque $503 \mathrm{ff}$; F. Jouan, Euripide et les légendes des Chants Cypriens 222-44; P. Rau, Paratragodia 19-26; C. BauchhensThüriedl, Der Mythos von Telephus in der antiken Bildkunst 8-19. For a defence of the assumptions made here about Telephus, see Additional note: 'Telephus at the "altar"', pp. roi ff. below.

$114 a$ See his important and illuminating article, 'Hestia-Hermès : sur l'expression religieuse de l'espace et du mouvement chez les Grecs', in Mythe et pensée chez les Grecs (2nd ed., 1969) 97-143 (the phrase quoted at p. IoI f.).

115 Vernant, op. cit. 103 and n. 23. On the ritual of $\kappa \alpha \tau \alpha \chi \chi^{\prime} c \mu \alpha \tau \alpha$, see especially Ar. Plutus $768-9,788 \mathrm{ff}$; Dem. xlv 74; Theopompus fr. 14 Kock; Hesychius

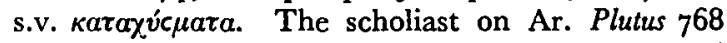
adds the significant detail that the newly acquired slave sat at the hearth for the 'pouring' ritual.

116 On the role played by women and slaves as outsiders in the structure of Greek myth and tradition about society and the fabric of social relations, see P. Vidal-Naquet, 'Esclavage et gynécocratie dans la tradition, le mythe, l'utopie', in Recherches sur les structures sociales dans l'antiquité classique 63-80; for the part played by women in Greek tradition on "inversions' of the social order, see Simon Pembroke, 'Women in charge: the function of alternatives in early Greek tradition and the ancient idea of matriarchy', in Journal of the Warburg and Courtauld Institutes $\mathbf{x x x}(1967) \mathbf{1}-35$. 
$\dot{\epsilon} c \tau \iota \hat{\nu} \nu$ for the ceremony of incorporation into the community by admission to the common meal."17 A 'Pythagorean' saying explicitly links wife and hearth with supplication: 'it is

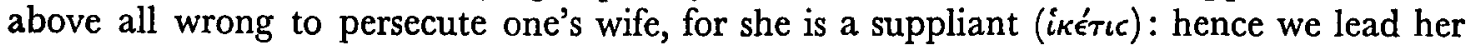
from the hearth, and hence also the (ritual of) taking by the right hand'.18 This admoni-

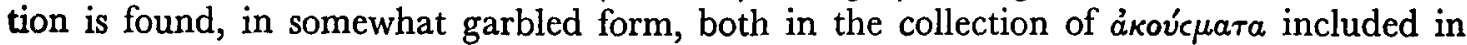
Iamblichus' Life of Pythagoras and in the pseudo-Aristotelian Oeconomica, on both occasions as a detached 'saying' without context. It is therefore impossible to be certain whether the hearth from which the wife is led is that of her house of origin or of her house of marriage: but if the latter, then the association with 'taking by the hand' makes the parallelism with, for example, Alkinoos' leading the suppliant Odysseus from the hearth complete. The

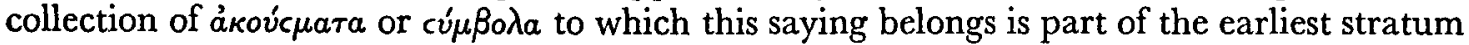
of our evidence for Pythagorean wisdom literature, and from the company in which it is found there are good grounds for believing it to be pre-Pythagorean and to go back at least to the archaic period.119 The association of wife, suppliant and hearth is, then, traditional.

Let us pursue this line of argument further. Julian Pitt-Rivers, in the two articles cited earlier, ${ }^{120}$ has put forward a general theory of hospitality and sanctuary in Mediterranean society, and of their inter-relation. In doing so he has laid particular stress on the role of women in the latter institution, starting from the part played by Arete in Odysseus' supplication on Scherie. He compares the rules of sanctuary among the Bedouin of Cyrenaica, and notes that in Arabic the word for sanctuary (aram) is derived from the same root as the words for womenfolk, sacred places and that which is prohibited or tabu. ${ }^{122}$ Since among the Bedouin Arabs a man's honour is at its most vulnerable through his womenfolk, there is an apparent contradiction in a custom whereby a stranger may secure the protection of a man by penetrating the women's quarters of his house or tent. Pitt-Rivers associates the harmlessness of the suppliant's invasion of the prohibited with his ritual submission to the authority of his host. 'By entering the women's quarters he tacitly renounces his power to affront. To enter them other than as a suppliant would be the gravest offence and a desecration of female purity, but a supplicant cannot affront for he throws himself upon the mercy of his host, and thereby forfeits all claim to the kind of honour by which he might impugn another man's. Having placed himself 'in balk', he cannot then challenge anybody until he resumes his liberty, and with it his vulnerability.'122

On the face of it there are obstacles in the way of applying this theory to the Greek evidence. Odysseus does not penetrate the prohibited women's quarters: he enters the public and 'secular' part of the palace, the megaron (Od. vi $304 \mathrm{f} . ; c f$. vii 53 , $139 \mathrm{ff}$.), where he finds Arete (uncharacteristically) feasting with the nobles of Phaeacia. There is nothing to suggest invasion of tabu. Moreover, the role of Arete in this scene is highly unusual, and has even been made the basis (as Pitt-Rivers notes) of theories of a primitive 'motherright'. Unusual, yes, but not quite unparalleled: we can add Themistokles' supplication of Admetos through his wife (Thuc. i 136.3 ), Telephus' supplication of Agamemnon through

117 Vernant, op. cit. 115-16.

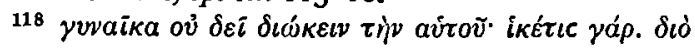

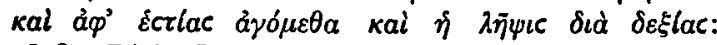

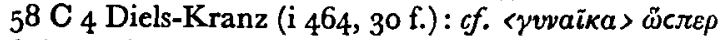

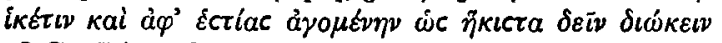
$5^{8} \mathrm{C}_{5}$ Diels-Kranz (i 465, i 7 f.). For the text of the pseudo-Aristotle passage, see W. Burkert, Weisheit und Wissenschaft $\mathrm{r} 52, \mathrm{n} .12$.

110 So, convincingly, Burkert, op. cit. 150-75, esp. $7_{2} \mathrm{f} . ; 45^{1-3}$.

180 Above, n. 108.

181 See further Abou A. M. Zeid in J. G. Peristiany (ed.), Honour and Shame: the values of Mediterranean society 253-6. E. L. Peters, 'Some structural aspects of the feud among the camel-herding Bedouin of Cyrenaica' (Africa xoxvii [1967] 261-82) puts forward a penetrating and illuminating analysis of vengeance and feud and their inter-relation among the Bedouin. Incidentally he offers an instructive example of sanctuary through physical contact, in the case of a man who had killed his paternal first cousin, and who re-entered the camp simultaneously with Peters, 'pitching his tent rope on rope with [Peters']' while Peters' in turn was pitched rope on rope with that of the camp's shaikh: as Peters points out, 'the tent is an area of sanctuary, and this extends to include the ropes also' (loc. cit. 264 and n. 1 ).

122 Échanges et Communications 865. 
Klytaimestra, ${ }^{123}$ and the supplication of Theseus by the Argive mothers through his mother, Aithra (the latter a case somewhat apart, since the suppliants are themselves women).$^{124}$ The last of these occurs in a public, if sacred, place: our sources are silent as to the precise geography of the other two cases. But in a society in which women (at least of the upper classes) ${ }^{125}$ lived, when indoors, in seclusion, in a separate part of the house normally kept locked, there are a priori grounds for expecting that to be faced by a man who is not a kinsman will normally be treated as an outrage, and in fact the entry of a male stranger into the presence of the free women of the household could be presented in a fourth-century Athenian court of law as clear evidence of outrageous behaviour and lack of ai $\delta \omega^{\prime} c^{128}$

Proper behaviour on the part of a male not a member of the kin is to remain outside those areas of the house in which he might encounter the free women of the household.127 The seclusion of women within the house indeed made it possible even to deny their existence in a court of law, and difficult to rebut such an argument. ${ }^{128}$ Thus the evidence suggests that for a male stranger to confront the free women is an assault upon the honour of the head of the household on a grave scale, and calling for immediate redress; hence that supplication which takes the form of a face to face approach to the wife or mother of the head of the household is, even more markedly than in supplication generally, an inversion of the normal and socially approved patterns of behaviour. We may perhaps connect with this another feature, which recurs in the stories of Telephus and Themistokles, and is found also, in a significantly different form, in Herodotus' story of the Scythian suppliants at the palace of Kyaxares (i 73-4): the surrendering to the suppliant of a son or sons of the supplicated. In Thucydides' account of 'Themistokles' supplication, Admetos' wife herself

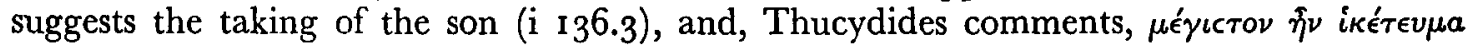

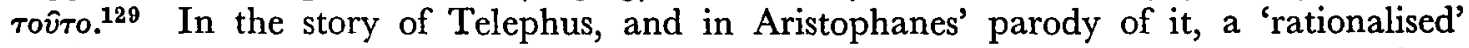
version of the act is prcsented, in which the act of taking the son is little more than a form of kidnapping or hostagc-taking. But the case of the Scythians is perhaps the most revealing. Here a company of Scythians arrive in Media as a result of what Herodotus describes as crácı: they are received and well treated as ikétaı. As a mark of honour, Herodotus reports, they are entrusted with the king's sons (to learn Scythian and archery!). The Scythians pass their time in hunting, but an occasion comes on which they return emptyhanded and are insulted for their failure by the king, Kyaxares. This is a grave breach of the proper behaviour of host to guest, and the Scythians respond to this slight upon their $\tau \mu \nu \eta^{\prime}$ with a monstrous revenge: they kill one of Kyaxares' sons and serve his dismembered body to his father as though meat from the hunt. ${ }^{130}$

Let us put together the significant features of these three stories. The suppliant is received and either before or after his reception comes into possession of the son(s) of the supplicated: in one, perhaps two versions, ${ }^{131}$ he is given the son by the wife of the supplicated, in the third, apparently, by the supplicated himself. In the first two cases, the suppliant obtains the object of his supplication, the rules of sanctuary are observed and he departs;

123 For Klytaimestra's role, see Hyginus Ior.2, and the arguments put forward by Handley (Telephus of Euripides $30 \mathrm{f} ., 36 \mathrm{f}$.).

124 Eur. Suppl. $8 \mathrm{ff}$., $24 \mathrm{ff}$, $9^{2} \mathrm{ff}$; ; Aithra is 'besieged'

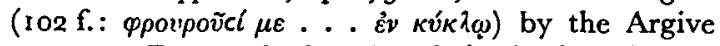
women at Demeter's altar, but their plea is addressed through her to her son.

${ }^{125}$ For the caveat, see G. E. M. de Ste. Croix, $C R$ $\mathrm{xx}(1970) 278$.

126 See Lysias iii 6-7, 23; Dem. xxi 79; xxxvii 45; xlvii 53, 55-6: compare Lys. xxxii I I; Isoc. Epist. ix 10. $\quad{ }_{127}$ See Dem. xlvii 60 and compare ibid. 38 . ${ }^{128}$ See in general, Lacey, The family in classical Greece $167 \mathrm{ff}$. with notes on $308 \mathrm{f}$.
129 137.1 : the reference is specifically to Themistokles' sitting at the hearth with the child in his arms; it is not altogether clear which element in the situation is uppermost in Thucydides' mind.

130 Commentators quote the obvious mythological parallels: Thyestes, Lykaon, and more distantly Tantalus, Prokne and Philomela. Once again it is not the historicity of Herodotus' story, but the association of ideas within it, that is important.

131 Hyginus' words (the best evidence we have) are: monitu Clytaemnestrae Orestem infantem de cunabulis rapuit [Telephus], minitans se eum occisurum nisi ... (Hyg. 101.2). 
the son is restored unharmed. In the third, the rules of hospitality are grossly breached by the host, and the son is murdered and eaten by the father. Thus in all cases the son is the pledge or symbol of the suppliant's proper treatment, and a departure from that proper treatment, but only a departure from it, results in the host's eating his own dismembered son. Now it is perhaps worth observing that in three of the mythological parallels for the motif of the dismembered son (Thyestes, Lykaon and Prokne-Philomela) ${ }^{132}$ the killing of the son and the subsequent feast are symbols of, and revenge for, an act of sexual assault which has destroyed the integrity of the house, and that it is the seducer who eats the dismembered body. The association of the ideas of sexual assault and supplication in these stories suggests that in the supplication stories too the surrendered son is a symbol of the integrity (yet also of the vulnerability) of the house, which is apparently threatened by the suppliant's arrival, but which, if both parties duly respond to the requirements of the laws of hospitality, remains in fact intact.

The role of women in Greek supplication, taken by itself, is perhaps too peripheral and too weakly attested to be made the basis of a general theory: the cases cited may all be aberrant. Moreover there is not in the Greek tradition anything to correspond with the peculiar and specifically Roman sanctity of the Vestal virgin, including for example, her power automatically to reprieve a man condemned to death by chance encounter. ${ }^{133}$ And yet the association between the sacred parts of the body (knees, chin and perhaps handsthe first two emblematic of a man's reproductive power), the sacred and inviolable centre of the house (the hearth) and the symbol of the house's continuity (the son) with iketeia, and other rites to incorporate outsiders is striking and may be thought to support the interpretation of the place of supplication within the fabric of Grcek social institutions which

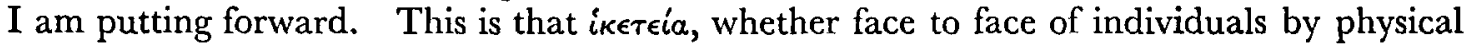
contact between them, or through a god by contact with his sacred place, is a mime of aggressive symbolical significance, directed at what must be kept inviolate, but a mime whose aggressive implications are contradicted by the inversion of normal competitive behaviour-patterns which is also a definitive feature of the ritual, symbolised in action by the abject lowering of the body in kneeling or crouching, and in words by the self-abasement

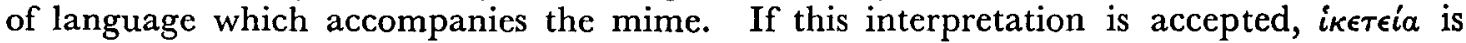
essentially an ambivalent ritual: a plea for the protection of an acknowledged and magnanimous superior (and thus an acceptance of harmless inferiority), but also a threat to the integrity of the person supplicated. The double-sidedness of the role of the suppliant is well brought out in Oedipus at Colonus. Oedipus threatens the inviolability of the grove of

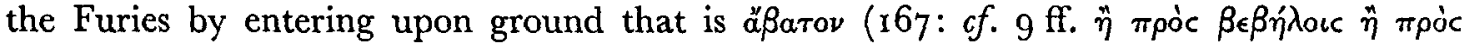

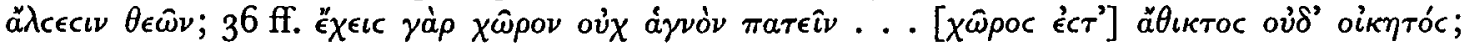
I $24 \mathrm{ff}$.). He has crossed the threshold of what is not permitted ( $155 \mathrm{f}$. $\pi \epsilon \rho \hat{a} c$ $\gamma \dot{a} \rho \pi \epsilon \rho \hat{q} \mathrm{c}$ ). Yet at the same time he is a strengthless and broken thing, old, blind, a creature who must be directed and moved in his every step. His supplication is dependent upon men whose power,

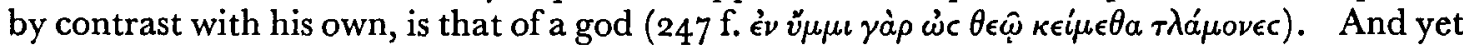
again: this broken and humiliated body is a source of power ( $576 \mathrm{ff}$, especially Theseus' dis-

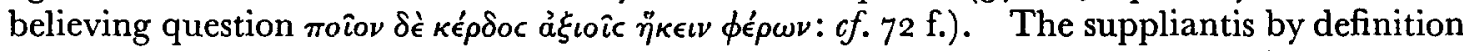
weak and defenceless: yet he carries with him the threatening power of what is 'beyond'.

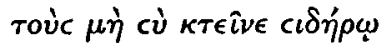

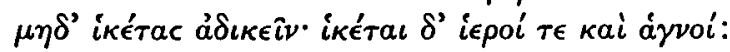

so the oracle of Zeus himself at Dodona. ${ }^{134}$

132 In the Lykaon story, grandson: Hesiod fr. 163 (Merkelbach-West).

193 Plut. Numa io; R.E. art. Vesta, col. 1735 (C. Kock); Kopperschmidt, Die Hikesie 16 . The connection with the hearth is again significant.

134 Paus. vii 25.1: the oracle introduces Pausanias' account of the anger $(\mu \eta \eta \dot{\nu} \nu \alpha)$ of Zeus $i \kappa \varepsilon \varepsilon \varepsilon_{0}$ against breaches of supplication: cf. ibid. 24.6 ; i 45.5 ; iii 17.9 . 


\section{Epilogue}

By the end of the fifth century, supplication, though a living thing, as the Thucydidean examples show, was becoming increasingly a ritual whose binding force was weakening in face of the counter-strain of political realities. Increasingly too what I have called 'figurative' supplication was becoming more or less emptily metaphorical. ${ }^{135}$ Thus frequently in the fourth century, petitioners of the Athenian Boule and assembly, when granted the object of their request, have their petition described by the formula évvo $\mu \alpha$

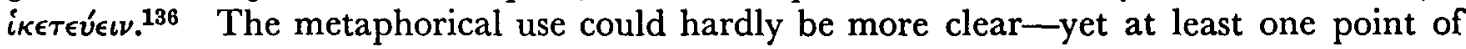
contact with older habits of thought persists: in those cases where the petitioners can be

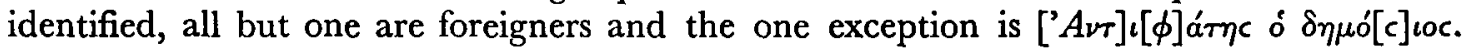
Thus the connection between suppliant and outsider survives even when the language of supplication has become in all other respects little more than an empty shell..$^{137}$ By degrees the extra-territoriality of the sacred gives way to the political extra-territoriality of diplomatic agreement and royal fiat. ${ }^{138} \quad i \kappa \epsilon \tau \in i a$ in the sense which $I$ have been describing is a religious and social institution characteristically of archaic and early classical Greece. But not of Greece alone: Pitt-Rivers has drawn attention to the evidence for sanctuary among the Bedouin $;^{\mathbf{1 3 9}}$ among the Tonga, a man may gain a 'stay of execution' if, while crawling on all fours, he can grasp the king's foot; among the Tswana, a man sentenced to corporal or even to capital punishment may escape execution of sentence if he can gain entrance to the hut of the chief's mother, the 'mother of his people'. ${ }^{140}$ In terms of social structure, the themes and details of these acts will differ from culture to culture, but in all of them we can detect a ritual one of whose functions is to bring an aberrant human being within the norms of the social order and to mitigate or resolve the crises which result when the community or its representative agent is confronted with what is 'outside'. They form, as van Gennep noted, a particular class of those rites which he categorised as 'rites of passage'. ${ }^{141}$

\section{Additional note: Telephus at the 'altar'}

(i) F. Jouan (Euripide et les légendes des Chants Cypriens 222-44) proposes a reconstruction of the Telephus which dispenses with the assumption that the episode of Telephus' supplication was described in a messenger-speech; so too P. Rau, Paratragodia $25 \mathrm{f}$. and n. I.

${ }^{135}$ See, for example, n. 24 above. Of some thirty references to supplication in Demosthenes, eighteen are cases of a speaker or his client 'supplicating' the

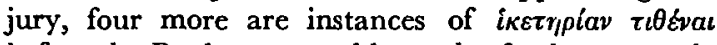
before the Boule or assembly, and a further example involves a speaker 'supplicating' the clerk of the court to read a document. It is perhaps worth noting that all the cases of speaker supplicating the jury are found in private cases, and all occur in either prooemium or epilogue.

${ }^{138} I G \mathrm{ii}^{2}$ 192.2; $211.1 ; 218.8 ; 276.5 ; 336 b .15$; $337.34 ; 404.4 ; 502.14$ : all of the mid-fourth century

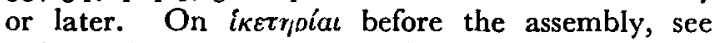
Arist. Ath. Pol. xliii 6; Rhodes, The Athenian Boule $55-7,72-3$. It is clear from references in the orators (Aeschin. i 104; ii 15; Dem. xviii 107; xxiv 12) that citizens could also 'place a suppliant's branch' before the Boule or assembly: the cases cited concern trierarchs in dispute over liturgies, an advvazoc petitioning the Boule to be restored to the register of invalids, and the oikeio of two Athenian citizens who had been captured at Olynthus. The case of Andocides (Andoc. i I I0-16) is somewhat different since the question of whether Andocides is or is not ă $\tau \iota \mu \circ c$ is precisely in dispute.

137 I do not mean to suggest that supplication in the traditional, 'complete' form did not take place in the fourth century, nor that it was never accepted: Xenophon is loud in praise of Agesilaus for his $\varepsilon v ं c \varepsilon \beta \varepsilon l \alpha$ towards suppliants (Ages. xi I: cf. ii 13); Arrian reports Alexander's grant of a $\alpha \varepsilon \iota a$ to the suppliants of Tyre (Anab. ii 24.5: the phrase $\not \delta \varepsilon \iota a v$ $\delta$ ¿óvou is itself indicative of changed attitudes: $c f$. Curtius iv 4.13). Arrian does not report Alexander's massacres of suppliants (D.S. xvii I 3.6, Thebes; Curtius vii 5.33, Branchidae). 138 See above, n. 21. ${ }^{139}$ See above, nn. 108 and 121 .

140 I. Schapera, Handbook of Tswana Law and Custom (2nd edn.) 295 f.; of. 74. Schapera points out that 'the fact that under such circumstances he entered the late Chief's house is a sign of his complete submission to the Chief. He is said "to have entered the Chief's belly", and comes out of it completely absolved.'

141 Les rites de passage (English translation) 26-35, esp. 32 . 
Jouan's grounds are familiar, but they are not cogent: Euripides could not have resisted the temptation to secure a coup-de-théatre by playing a scene of such tense excitement before the audience. Consideration, for example, of Ion, where two moments of comparable excitement occur, one the attempt on Ion's life (II22-28: messenger-speech), the other Ion's attempted revenge and Kreousa's supplication (1250-319: on stage) should be enough to discourage such a priori generalisation. Jouan's version of the scene (op. cit. 236-40) involves Telephus' throwing off his beggar's rags, seizing the infant Orestes, leaping onto the altar, drawing a sword and holding it at Orestes' throat, while Agamemnon also draws his sword and Klytaimestra throws herself between the two. It is reasonable to regard this sequence of actions as highly unlikely in the Euripidean theatre: the nearest analogy would be the exodos of Orestes, and, quite apart from questions of chronology, the anomalousness of that scene has long been a stumbling-block for critics. I believe that the messenger-speech hypothesis remains by far the more plausible. The highly uncertain examples of the recognition-scenes of Alexandros and Kresphontes (cited in support by Jouan, op. cit. I 30, 237) cannot be used to prove anything about Telephus, since only those plays which survive complete can produce evidence as to Euripides' dramatic technique, and the two scenes in question remain problems to be solved: to argue otherwise is merely petitio principii. The vase-evidence also pressed into service by Jouan and by Rau can equally tell against them: vase-painters commonly illustrated scenes from Euripidean messengerspeeches (examples: Medea, ed. D. L. Page, lvii ff., Trendall-Webster, Illustrations of Greek Drama, II I.3.35; Andromache, Trendall-Webster, I I I.3.9; Hippolytus, ibid. I I I.3.23-4 and probably Aigeus, ibid. III.3.I-2; Alkmene, ibid. III.3.6-8; Antiope, ibid. III.3.I4-I5; Hypsipyle, ibid. I I 1.3.-25-6; $c f$. Bond, Euripides' Hypsipyle $97 \mathrm{f}$. on fr. 18), Meleager, TrendallWebster, I I I.3.39; $f f$. Page, Greek Lit. Pap. no. 27, 7 ff.). The vase-paintings are discussed by Christa Bauchhens-Thüriedl, Der Mythos von Telephos in der antiken Bildkunst 18-32, esp. $26 \mathrm{ff}$.: she adopts Webster's suggestion of a messenger-speech (p. 32). One detail in the Telephus vases may be significant. On three at least of the vases (Trendall-Webster, I I 1.3.47-9) a woman who by her dress should be a servant and is certainly not Klytaimestra (who is also present) either runs away or stands in an attitude of horror: it seems plausible to connect this feature with the omnipresent 'internal audience' of the Euripidean messengerspeech, whose reactions to the horrors of the events described form a constant 'punctuation point' of messenger-speech structure.

One further point may be worth making: from all three plays (Telephus, Kresphontes, Alexandros) words are preserved which have been more or less plausible identified as spoken by one or other of the central figures of the coup-de-théatre scene at its climax (Telephus: fr. 106 Austin $=700 \mathrm{~N}^{2}$, fr. 143 Austin, ? spoken by Telephus; Kresphontes: fr. 74 Austin = $45^{6} \mathrm{~N}^{2}$, ? spoken by Merope; Alexandros: $f r$. 44 Snell $=5^{8} \mathrm{~N}^{2}$, ? spoken by Alexandros): however, even if all these attributions are correct, it does not follow that such words must have been uttered by the characters in question on stage, since another of the distinctive features of the messenger-speech is the presence of verbatim quotation of words spoken by the characters involved.

In any case it is clear that earlier versions of the Telephus story set the supplication scene inside Agamemnon's palace: see, for example, the r.-f. cup fragments in Boston of the time of Aeschylus ( $A R V^{2}$ 817, $2=$ Paralipomena 420; Caskey-Beazley, Attic Vase Paintings in the Museum of Fine Arts, Boston, iii 54-7: Telephos painter).

(ii) H. Metzger (Mélanges C. Picard, ii [= Revue Archéologique, xxxi-xxxii (I948)], 746-5I, repeated in Représentations dans la céramique attique du $4^{e}$ siecle $287 \mathrm{f}$.) has suggested that the scene of 'Telephus' supplication was 'played' in Euripides' play not in Agamemnon's palace, but in the $\tau \epsilon \epsilon \epsilon \nu \circ c$ of Apollo Lykeios at Argos: the suggestion has now been adopted by Jouan (op. cit. 226, 228 f.), by Webster (Tragedies of Euripides $46 \mathrm{f}$., 302), by TrendallWebster (I I . 3, 47-9), and most recently by Bauchhens-Thüriedl, op. cit. 27, 30-2). This 
suggestion, if it is accepted, would, of course, put out of court an equation between the 'altar' and the hearth of Agamemnon's place, and remove any parallelism between this scene and the supplications of Odysseus on Scherie and Themistokles at the palace of Admetos (for which see pp. 97 above). The evidence for the suggestion is an early fourthcentury Attic r.-f. calyx-krater in Berlin (best photograph, Trendall-Webster, 1 I I.3, 47) showing the scene of Telephus at the 'altar' with, in the background, a seated Apollo and to his left a sacred bay (?) with votive pinakes: these features Metzger interprets as locating the scene in a sanctuary of Apollo and proceeds (on this assumption reasonably) to identify the sanctuary with that of Apollo Lykeios in the agora at Argos (for which see schol. Soph. El. 6; Paus. ii 19.3; Plut. Pyrrh. xxxi 7), citing in confirmation Eur. fr. 106 Austin $=700 \mathrm{~N}^{2}$,

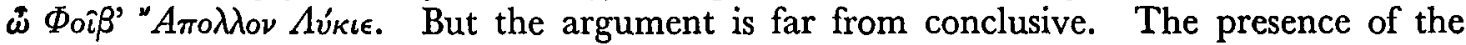
god may be intended to do no more than remind us that it was as a result of Apollo's oracle (Hyginus I0I: schol. Arist. Clouds 919 adds that it was the Pythian Apollo) that Telephus came on his dangerous journey to Argos: for comparable examples of divine presence on vases of the period, see Metzger, loc. cit. 750, n. 7 and Représentations 316 f., 323 (without implications as to the location of the scene depicted). As for the tree with votive offerings, it is perhaps worth suggesting that the vase-painter intends to recall the oracle which he

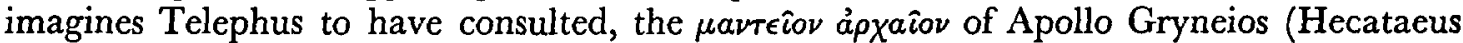
fr. 225 Jacoby), famous above all for its grove of trees (Paus. i 21.7 ; Vergil, Ecl. vi 72 with Servius' note) and only a short distance from the bay known as ' $A \chi \alpha \iota \hat{\omega} \nu \lambda_{\iota \mu} \eta_{\nu}$ where legend placed the landing of the Greeks before their clash with Telephus (ps.--Skylax 98). Otherwise, the consequences of accepting Metzger's hypothesis are unwelcome; either a stage representation of the scene set in the Argive agora (such as Jouan and Rau suggest, on which see above), or the necessity of removing four characters (Klytaimestra, Telephus, Agamemnon-and Odysseus, according to Webster, op. cit. $46 \mathrm{f}$.-plus servant) from the scene at different moments in the play and on different errands to go to the sanctuary of Apollo for purposes which remain obscure, three of whom must then return immediately after the messenger-speech to play the following scene. It seems more economical to suppose either that the interpretation of the vase is mistaken or that the vase-painter is adding from his own imagination to what he found in the text of Euripides' play.

University College of Swansea

JoHN Gould 